\title{
Almanya'daki Türkiye Asıllı Gençlerin Eğitim Başarısı ve Eğitim Fırsatları
}

\author{
Taylan Acar ${ }^{1} \odot$
}

\section{Öz}

Bu çalışma, Almanya Ulusal Eğitim Paneli Araştırmasıi (UEPA) tarafindan 2010-2011 akademik yılından itibaren boylamsal yöntemle yürütülen çalışmalara dayanarak, Almanya özelinde, Türkiye asıllı gençliğin eğitime erişim ve eğitim firsatları alanlarında yaşadığı eşitsizlikleri nicel olarak incelemektedir. Çalışmanın bulgularına göre Türkiye asıllı genç nüfus, 5. ve 9. sınıf düzeyinde hem Almanca hem de matematik alanlarında en dezavantajı göçmen grubudur. Ayrıca oransal olarak, üniversite ve meslek yüksek okullarına geçişe firsat sağlayan akademik lise öğrenciler arasında da Türkiye asıllı öğrenciler en az temsil edilen gruptur. Türkiye'den Almanya'ya göçün ilk başladığı tarihten bu yana 50 yıl geçmiş olmasına rağmen, Türkiye asıllı genç nüfus başta gündelik hayatta Almanca kullanımı, arkadaşıı ağları ve ikamete dayalı etnik tecrit alanlarında olmak üzere büyük sorunlar yaşamaya devam etmektedir. Parçalı asimilasyon kuramı çerçevesinde, farklı göçmen gruplar tarihsel göç koşullarına bağlı olarak gittikleri ülkelerin toplumlarıyla farklı bütünleşme süreçlerinden geçerler. Almanya özelinde, diğer göçmen gruplar zamanla Alman toplumuyla bütünleşirken, Türkiye asıllı göçmen nüfusun bütünleşmesindeki sıkıntılar daha genç nesilleri etkilemeye devam etmektedir.

\section{Anahtar Kelimeler}

Türkiyeli göçmenler • Göçmen bütünleşmesi • Eğitim eşitsizlikleri • Parçalı asimilasyon kuramı • Almanya

1 Sorumlu Yazar: Taylan Acar (Dr. Öğr. Üyesi), Boğaziçi Üniversitesi, Fen-Edebiyat Fakültesi, Sosyoloji Bölümü, İstanbul, Türkiye. Eposta: taylan.acar@boun.edu.tr

Atıf: Acar, T. (2018). Almanya'daki Türkiye asıllı gençlerin eğitim başarısı ve eğitim firsatları. Sosyal Siyaset Konferansları Dergisi, 75, 153-183. http://dx.doi.org/10.26650/jspc.2018.75.0012 


\title{
Educational Achievement and Opportunities among Turkish Migrant Youth in Germany
}

Taylan Acar $^{1}$

\begin{abstract}
Using data from the German National Educational Panel Study (NEPS), this study provides a quantitative overview of educational achievement and opportunities among Turkish youth in Germany. The findings show that students with a Turkish background are the most disadvantaged group at the fifth and ninth grade level in the fields of German and mathematics. Moreover, proportionally, they are the least-represented group among academic high school track students; the track provides opportunities for admission to universities and universities of applied sciences. Fifty years after the first migration from Turkey to Germany began, Turkish youth have had problems regarding using German in everyday life, friendship networks, and residential segregation. According to the segmented assimilationist perspective, different immigrant groups experience different levels of accommodation in destination countries. In the German context, data show that other immigrant communities gradually adapt to German society one way or another, whereas the problems of Turkish accommodation are passed on to younger generations.
\end{abstract}

\section{Keywords}

Turkish immigrants - Immigrant accommodation - Educational inequalities - Theory of segmented assimilation • Germany

1 Corresponding author: Taylan Acar (Dr. Lecturer), Boğazici University, Faculty of Letters, Department of Sociology, Istanbul, Turkey. Email: taylan.acar@boun.edu.tr

To cite this article: Acar, T. (2018). Educational achievement and opportunities among Turkish migrant youth in Germany. Sosyal Siyaset Konferansları Dergisi, 75, 153-183. http://dx.doi.org/10.26650/jspc.2018.75.0012 


\section{Extended Summary}

Recently, the Turkish immigrant population in Europe became a popular topic of discussion because of the political tension between Turkish and European governments during the 2014 presidential election, the 2016 Constitutional referendum, and the 2018 general elections. In July 2018, the conviction of members of the terrorist organization National Socialist Underground (NSU) and the resignation of the Turkish-German football player Mesut Özil from the German National Team highlighted the problems of accommodation and integration of Turkish communities to respective destination societies in Europe. Despite this, the major discussion in Turkish media and politics did not focus on the long-term disadvantages and inequalities the Turkish community experience. A particularly significant issue is that five decades after the first labor migrants arrived in Germany, the Turkish youth still experience dire disadvantages in terms of educational opportunities and labor market participation. Studies show that even among the younger generations, the educational disadvantages of Turkish youth do not disappear as they do for immigrant youth from other countries of origin. Developing a segmented assimilationist framework, this study discusses the educational inequalities that Turkish youth experience and the potential determinants behind them.

\section{Data and Methods}

This study uses data from the German National Educational Panel Study (NEPS), which has been conducted every three years by Leibniz Institute for Educational Trajectories (LIfBi) since the 2010-2011 academic year (Blossfeld, Roßbach, and von Maurice, 2011). It relies on nationally representative information collected from SC3-Class 5 and SC-4 Class 9 samples conducted with the paper-and-pencil (PAPI) method. In the fifth class sample, there are 5,102 students, whereas in the ninth class sample, there are 13,793 students. In both samples, the Turkish students compose $6 \%$ of the total sample size, which is an accurate reflection of the student-age immigrant population with Turkish background.

Moreover, these surveys provide detailed information about students' socioeconomic and migration status, their family and household situation, and their expectations for the future. Unlike census data and other available surveys in Germany, the NEPS questionnaire is also able to identify third generation immigrant students, as it asks them not only their parents' but also their grandparents' migration background. By examining the inequalities experienced by Turkish youth, the current study develops a comparative approach and examines the educational standing of Turkish students in relation to that of native Germans and immigrant students from other countries of origin. This study introduces a short history of migration to Germany in the second half of the twentieth century and shows how motives for immigration and "the context of arrival" vary among immigrant communities from different countries and regions of origin (Portes and Rumbaut, 2001). 
The motives for immigration and the social and historical context at the time of arrival shape the opportunity structures that are available for immigrant communities.

\section{Findings and Discussion}

The study first presents the existing disadvantages of students with Turkish backgrounds in track placement in secondary education and educational performance in reading and math. In both areas, the Turkish students appear to be the most disadvantaged immigrant group, falling behind all other immigrant groups. In particular, Turkish students have the lowest levels of opportunity to enter universities and universities of applied sciences after high school graduation because they are the least likely group to attend academic high schools (Abitur). Their reading ability is a full standard deviation behind their German peers and at least half a standard behind all other immigrant groups. Relying on a segmented assimilationist perspective, the study then discusses three potential determinants to interpret the existing inequalities the Turkish students face: parental educational attainment and socioeconomic status (SES); use of German and friendship ties; and residential segregation.

The detailed information from both the fifth and ninth grade samples reveal that students from Turkey not only come from families with lowest levels of SES, but also are less likely to be exposed to German when they grow up and less likely to have German friends. According to their own reports, compared to other migrant students, they are also the group who lives in neighborhoods with the highest levels of co-nationals from Turkey. Thus, the level of residential ethnic isolation is highest among students with Turkish origins. To sum, the Turkish community, according to NEPS samples, are not only in a disadvantaged situation within the German social status hierarchy, but also experience the highest levels of isolation from the rest of the German society and are least likely to use the German language. In conclusion, to challenge the existing educational inequalities and the eventual problems related to labor market integration of Turkish youth, policies primarily should promote early exposure to and use of German language among Turkish children. In addition, the existing ethnic isolation of the Turkish community should also be tackled to facilitate the integration of Turkish youth in the long-term. 


\section{Almanya'daki Türkiye Asıllı Gençlerin \\ Eğitim Başarısı ve Eğitim Fırsatları}

Avrupa'daki Türkiye asıllı vatandaşların konumu, yaşadıkları ve Avrupa toplumlarıyla bütünleşmesi son yıllarda sürekli olarak gündeme geldi. Önce, 2014 Türkiye

Cumhurbaşkanlığı seçimlerinde, daha sonra 2016 Anayasa Referandumu ve 2018 milletvekilliği seçiminde Almanya ve Hollanda hükümetleriyle yaşanan siyasi kriz, 2018 Temmuz ayı başında Almanya'da göçmenlere karşı seri cinayetler isteyen NSU (Nasyonal Sosyalist Yeralt1) isimli terör örgütü yöneticilerinin mahkum edilmesi ve son olarak da Alman Ulusal Futbol Takımı oyuncusu Mesut Özil'in, basının ve Alman Futbol Federasyonu Başkanı'nın ayrılıkçı davranışlarını gerekçe göstererek Almanya Ulusal Takımı'nı bırakması, Türkiye asıllı topluğun yaşadıkları Avrupa ülkeleriyle ve özellikle Alman toplumuyla bütünleşme sorunlarının devam etmekte gerçeğini gündeme getirdi.

Her ne kadar bu sorunlar sürekli olarak gündeme geliyor olsa da Türkiye siyasi coğrafyası ve basınında Almanya ve genel olarak Avurpa'da yaşayan Türkiye asıllı toplumun yaşadığı bu sorunlar derinlemesine tartışılmıyor. Genellikle seçimlerde iktidar partisine verdiği destekle gündeme gelen bu topluluğun yaşadığ sıkıntılar ne yazık ki Türkiye gündeminde kendine sınırlı olarak yer bulabiliyor.

Bu çalışmada, Almanya'da yaşayan Türkiye kökenli gençliğin eğitime erişim ve eğitim fırsatları konusu nicel bir bakışla ele alınacaktır. Bu iki alanda var olan yakın zamanda üretilmiş yazından ve kendi özgün çalışmalarımdan güncel örneklerle, makale, Türkiye kökenli gençlerin Almanya'da eğitime, özellikle yüksek öğrenime erişim ve işgücü piyasasına katılmada olası sorunlar yaşamaya devam ettiğini gösterdikten sonra bunun nedenlerini tartışacaktır.

\section{Kavramsal Çerçeve}

Avrupa ve Almanya'da yaşayan Türkiye asıllı toplulukların var oldukları ülkelerdeki toplumsal ve iktisadi yaşamla bütünleşme imkanları konusuna, Portes ve çalışma arkadaşları tarafından ortaya atılan ve daha sonra geliştirilen 'parçalı asimilasyon' yaklaşımıyla bakmak uygun olacaktır (Portes ve Zhou, 1993). Bu görüşe göre farklı göçmen topluluklar varış ülkesine gelişlerinden sonra, içinde bulundukları toplumlarla farklı şekillerde bütünleşir ve uyum sağlarlar. Belli göçmen gruplar toplumsal yaşama kısa sürede ayak 
uydurup toplumsal hayatın bir parçası olurken, belli gruplar için bu ayak uydurma süreci daha uzun süreler alabilmektedir.

Portes ve arkadaşlarına göre bu farklılıkların altında yatan iki temel neden vardır. Bu nedenlerden birincisi, varılan toplumun göçmenlere karşı olan davranışları ve açıklığı, ikinci ise göçmen topluluğun tayin edici belli başlı özellikleridir (Portes ve Rumbaut, 2005). Birinci neden, ev sahibi ülkedeki bağlamla ilgilidir. Burada kritik olan nokta, göçmen topluluğun hangi amaçla göç ettiğidir. Göçmen topluluğun işçi göçüyle mi, beyin göçüyle mi, iltica ile mi, ya da aile birleşmesi sonucu mu göç ettiği önemlidir. Çünkü var olan göçün hangi tip göç olduğu, göçmen topluluğa bütünleşme için sunulacak fırsatlar ve toplulukların göçten beklentilerini yakından etkiler. İşçi göçüyle gelmiş grupların, her ne kadar çalışma yaşamına katılabilseler de uzun vadede hem kendileri hem de kendinden sonra gelenler için yukarıya doğru toplumsal hareketlilik firsatları sınırlıdır. Ayrıca var olan toplumsal bağlam, işçi göçüyle gelen göçmen grupları toplum arasına alma konusunda daha kapalıdır. İşçi olarak geldikleri için bu göçmenlerin toplumun eşit bireyleri olarak görülmeleri daha az olasıdır ve kimi zaman ev sahibi toplumun belli kesimleri tarafından horlanırlar. En önemlisi de siyasi iktidar bu göçmen grupları topluma ayak uydurmaya teşvik edici önlemler almaz ve politikalar üretmez.

Göçmenlerin uyum şansını yakından etkileyen bir diğer neden de göçmen grupların tayin edici sosyoekonomik, kültürel ve demografik özellikleridir. Burada Portes daha sonraki yayınlarında eğitim düzeyi ve mesleki yetenekler gibi özelliklere odaklanırken (Portes ve Rumbaut, 2001), Zhou ve çalışma arkadaşları, Asyalı göçmenlerin Amerika Birleşik Devletleri'ndeki deneyimlerine odaklanarak, daha kültürel bir yaklaşımla göçmenlik meselesini anlamaya çalışmışlardır (Bankston ve Zhou, 2002; Zhou ve Bankston, 1998). Özellikle din, burada önemli bir etkendir.

Almanya'daki Türkiyeli göçmenlerin, Hollanda'daki Faslı göçmenlerin, İngiltere'deki Pakistanlı göçmenlerin içinde bulunduğu durum, din ve Müslüman karşıtllğının bu grupların uyumunda sorunlar yarattığı izlenimini verse de sorunun din ile mi yoksa bu grupların ev sahibi toplumlardan daha az eğitimli olmalarıyla mı ilgili olduğunu anlamak güçtür. Her iki yaklaşıma yönelik bulgular olsa da, büyük ihtimalle her iki etmenin de ayrı ayrı belirleyiciliği vardır. 
'Parçalı asimilasyon' fikrinin ABD'de ve Avrupa'da bir ara çok popüler olmasına ve bir dizi araştırmaya ilham vermesine sebep olan en önemli özelliği, yukarıda sayılan nedenler yüzünden göçmen gruplarının farklı bütünleşme izlekleri gösterebilmesini öngörme esnekliğine sahip olmasıdır (Kroneberg, 2008). Parçalı asimilasyon kuramcıları, hem kendilerinden önce gelen klasik asimilasyoncu hem de kendilerinden sonra gelen yeni-asimilasyoncu araştırmacıları, tek tip bir bütünleşme süreci öngörmekle eleştirmiş; göçmenlik deneyimlerinin var olan ülkenin bağlamına oturtmayı öne sürmüşlerdir.

Sonuç olarak 'parçalı asimilasyon' kuramı, farklı grupların farklı bütünleşme deneyimlerine sahip olabileceğini ortaya koyması ve göçmenlik deneyimlerini tarihsel bağlamına oturtması ve farklı bağlamlara göre esneklik gösterebilmesi açısından önemli bir kuramdır. (Acar, 2016). 'Parçalı asimilasyon' bakışı Almanya' daki Türkiye kökenli toplumun, diğer göçmen gruplarından farklılık gösteren deneyimlerine ve genç nesil göçmen gruplarının eğitim ve işgücü piyasasına erişiminde yaşadığı sorunlara da açıklık getirebilecek bir çerçeve sunmaktadır.

\section{Almanya'da Göçmen Grupların Eğitim Fırsatları ve Başarıları}

Almanya'da son yıllarda, göçmenlerin eğitim firsatları ve başarıları üzerine yapılan araştırmaların sayısında bir artış göze çarpmaktadır. Özellikle 2003 yılında yaşanan “PISA Şoku”ii (Hanushek, 2005), Alman hükümetinin göçmenlerin eğitim alanında yaşadığı eşitsizlikliklere daha yakından eğilmesine yol açmıştır. Alman hükümeti bu eğitim şokunun ardından Almanya'nın bir göçmen ülkesi haline geldiğini zımnen de olsa itiraf etmiş, göçmen topluluklarının yaşam şartları ve gelecekte Almanya'ya gelecek göçmenlerle ilgili politikalar siyasal tartışmanın üst sıralarına taşınmıştır.

Akademik yazında eğitimle ilgili eşitsizleri anlamak için öncelikle öğrencilerin ailesinin eğitim düzeyi ve mesleki statüleri göz önüne alınır (Blau ve Duncan, 1967). Toplumsal sınıflar ve statü gruplar hiyerarşisinin bu vesileyle genel olarak kendini yeniden ürettiği varsayılır (Grodsky ve Jackson, 2009). Ancak göçmenlik konusu çerçeveye girdikçe ebeveynlerin eğitim düzeyi ve çocukların eğitim başarı ve firsatları arasındaki direkt ilişki daha çetrefilli hale gelir. Öncelikle, kültürel bütünleşme, dil ve ayrımcılık sorunları yüzünden, eğitimli ebeveynlere sahip olsalar da göçmenlik geçmişi olan çocuklar, farklı eğitim fir- 
satları ve şansları tecrübe edeceklerdir (Kroneberg, 2008). Yani göçmenlik durumu sebebiyle, ebeveynlerin toplumdaki statüsüyle çocukların eriştiği fırsatlar ve yakaladığı başarılar arasındaki doğrudan ilişki zayıflayacaktır. Eğitimli ve orta sınıflara mensup ailelerin çocukları bile, göçmenlik durumu yüzünden yerli grupların sahip olduğu firsatlar manzumesinden mahrum kalabilirler.

Almanya bağlamında başta Türkiye'den gidenler olmak üzere, işçi göçüyle Almanya'ya gelen göçmen grupların eğitim başarısı ve eğitim firsatlarına erişimi alanındaki sorunlar, bu grupların sosyoekonomik hiyerarşideki konumları ve mesleki prestijleri ile açıklanmıştır (Diefenbach, 2008; Kristen vd., 2011). Bu grupların ilk olarak Almanya'ya misafir işçi olarak gelmelerinin uzun vadede yeni nesillerin eğitim firsatlarına erişimini geciktirdiği sonucuna ulaşılmıştır (Kalter ve Granato, 2007).

Ancak mesleki prestij ve sosyoekonomik konum göçmen grupların yaşadığı fırsat eşitsizliklerini açıklamakta yeterli değildir. Göçmen topluluklar aynı zamanda bulundukları kentlerde göçmen yoğunluklu ve etnik anlamda tecrit edilmiş mahallelerde ikamet ettikleri için göç ettikleri toplumdan genel olarak tecrit olabilirler. Bahsedilen göçmen tecridi, bu mahallelerde büyüyen gençliğin ev sahibi toplumun ana dilini daha az kullanmasına, kullansa da becerilerini geliştirememelerine ve yerli gruplara mensup akranlarıla arkadaşlıklar ve bağlar kuramamasına yol açabilir. Almanya'da ikamete dayalı tecrit ile ilgili araştırmaların sayısı sınırlıdır. Ancak, hem eğitim ve Almanca başarısı (Kristen ve Olczyk, 2013) hem de Alman vatandaşların toplumsal ağlarına erişme konularında (Kalter, 2011) ikamete dayalı tecritin önemli bir rolü olduğuna dair bulgular mevcuttur. Daha da önemlisi, Almanya' da öğrenciler ikamet ettikleri mahallere göre okullara kayıt olabildiklerinden, göçmen ailelere mensup öğrenciler de göçmen sayısının yüksek olduğu okullarda okumaktadırlar (Kristen, 2003). Ayrıca, göçmen mahallelerindeki okullar yatırım, öğretmen kalitesi ve altyapı olarak ortalama bir okul kalitesinde olmadıkları tespit edilmiştir (Kristen, 2003; Orfield ve Lee, 2005).

\section{Türkiye'den Avrupa'ya Göçün Kısa Tarihi}

Türkiye'den Avrupa'ya, özellikle “Acı Vatan” Almanya'ya dair göç hikayelerine her Türkiye Cumhuriyeti vatandaşı aşinadır. Yıllarca şiirlere, şarkılara, filmlere konu olmuş bu tarih, Almanya'nın İkinci Dünya Savaşı sonrasında 
büyüyen ekonomisinin yaşadığı emek gücü noksanlığı sonucu, çeşitli Akdeniz ülkeleri, Eski Yugoslavya ve Türkiye'den hükümetler arası anlaşmalarla işçi ithal etmesiyle başlar (Türkiye'den işçi alımı 1961 yılında başlamıştır, bkz. Kogan 2011, s. 92). Bu dönemde Alman hükümeti, bu işçilerin Almanya'da geçici olarak bulunacağını düşünmüş ve onlara "misafir-işçi”" (Gastarbeiter) muamelesi yapmıştır.

1973 petrol krizi sonrasında yaşanan ekonomik durgunlukla birlikte hükümetler arası işçi anlaşmalarına son verilmiş ve yasal işçi alımı sona ermiştir. 1970'lerin geri kalanında ise, Türkiye'den Almanya'ya daha ziyade yasadışı yollarla işçi göçü gerçekleşmiştir. Daha önemlisi, önceki dönemde işçi göçüyle Almanya'ya gelmiş erkek işçiler, aile birleşmesi yoluyla eşlerini ve çocuklarını da Almanya'ya getirmeye başlamıştır (bkz. Abadan Unat, 2002). Bu yüzden, Almanya'daki Türkiyeli toplumunun demografik yapısı değişmiştir. İşçi göçü başladığından beri ilk kez göçmenler arasındaki işsizlik oranı bu dönemde ilk kez Almanya'nın genelindeki işsizlik oranının üzerine çıkmıştır (Kalter ve Granato, 2007). 1980'ler sonrasında ise aile birleşmeleri ve yasad1ş1 işçi göçüyle Türkiye'den Almanya'ya göç sürmüştür.

Ayrıca 12 Eylül darbesi sonrasında, önemli sayıda Kürt vatandaş da diğer Avrupa ülkelerinin yanı sıra Almanya'ya iltica etmiştir.

1990'ların başında ise Almanya'ya eski Sovyetler Birliği’nden (SSCB) büyük bir göç dalgası yaşanmıştır. İkinci Dünya Savaşı sonrası sosyalist cumhuriyetlerde yaşamlarını sürdürmüş olan bu Alman kökenli göçmenler (Aussiedler), SSCB'nin dağılmasıyla birlikte her yıl yüzbinlerle ifade edilebilecek sayılarla Almanya'ya gelmişlerdir. Bugün eski SSCB'den gelen Alman kökenli göçmenler, Türkiyeliler'den sonra Almanya'daki en kalabalık göçmen grup haline gelmişlerdir. Ancak bu grup için göçmenliğin bağlamı işçi göçü değildir. Aksine, etnik olarak Alman oldukları için bu göçmenler "geriye-göç" etmişlerdir. Geriye-göç eden eski SSCB asıllı bu gruba Alman hükümeti işçi göçmenlere nazaran çok daha farklı muamele etmiştir. Kendilerine toplumla bütünleşmeleri için çeşitli destekler sunulmuş ve derhal Alman vatandaşlığına alınmışlardır (Wegmann, 2014). Hükümet bu göçmenlere, Türkiyelilerin aksine, kendilerini Almanya'da evlerinde hissettirmiştir. Bu dönemde aynı zamanda Alman toplumu genel olarak göçmenlik konusunda katı tutumunu yumuşatmıştı ve yaygın bir şekilde "entegrasyon” konusunu tartışmaktaydı (Schulz ve Leszczensky, 2016). 
Bu iki grup, son yıllarda yaşanan başta Suriyeliler olmak üzere mülteciler tartışmasına kadar siyasi alanda Almanya'daki göç konusunun başlıca aktörleri oldular. Hem toplulukların büyüklügü hem de bütünleşmeyle ilgili yaşadıkları sıkıntılar neticesinde son 15 yıl ülkede göç gündemini işgal ettiler.

Günümüzde, Almanya'da Türkiye asıllı göçmenlik geçmişi olanların sayısının üç ila dört milyon arasında olduğu tahmin edilmektedir (Tarelli vd., 2012). Nüfus sayımı soru kâğıdının üçüncü nesil göçmenleri tespit edememesi ve Alman vatandaşlığına geçenlerin sayısının yüksek olması tam rakamı hesaplamayı güçleştirmektedir. Göçmenlerin geneline bakıldığında, Almanya nüfusunun beşte birini göçmenler veya göçmenlik geçmişine sahip olanlariii oluşturmaktadır (Federal İstatistik Bürosu, 2011). Ancak her ne kadar hem Türkiye'den hem de eski SSCB'den göç durmuş olsa da (hatta Türkiye'den giden işçiler emekli olmaya ve Türkiye'ye dönmeye başlamış durumdadırlar), genç nüfus arasında göçmenlerin oranı daha yüksektir. 2010 Nüfus rakamlarına göre 25 yaşından küçük nüfusun \%29’u, 15 yaşından küçük nüfusun

\%32'i göçmenlik geçmişine sahiptir. Bu rakamın 65 ve üstü nüfusta yalnız \%8 olması, Almanya'nın göçmen nüfusunun halen genç olduğunu göstermektedir. (Son nüfus sayımı rakamlarına göre yazarın kendi hesaplamaları, Federal İstatistik Bürosu, 2011). Bu yüzden eğitime erişim ve işgücüne katılım konuları göçmenlikle yakından ilintilidir. Bugünden bakıldığında, önümüzdeki yıllarda da Almanya'da göçmenler iş yaşamına katılımla ilgili sıkıntılar yaşamaya devam edeceklerdir.

Çalışmanın geri kalanında Almanya'daki Türkiye asıllı gençliğin eğitime erişime ve eğitim fırsatlarına odaklanılacaktır. Çalışmanın amacı, ilk Almanya'ya gidişlerinin üzerinden 50 yıldan fazla süre geçmiş olmasına rağmen, Türkiyeli göçmen gençliğin hâlâ en dezavantajlı grup olmaya devam ettiğini göstermek ve bunun olası nedenlerini tartışmaktır.

\section{Veri Kaynă̆ı ve Metot}

Çalışmanın veri kaynağını, temel olarak, Leibniz Eğitim Enstitüsü (LIfBi) tarafından 2010-2011 yıllarında ilki yapılan Ulusal Eğitim Paneli Çalışması (UEPA) oluşturmaktadır (Blossfeld, Roßbach ve von Maurice, 2011). UEPA çalışması, boylamsal yöntemle üç yılda bir, aynı öğrenci örnekleminin eği- 
Tablo 1

Almanya'daki başlıca göçmen gruplar ve göç hareketlerinin arka planı*

\begin{tabular}{|c|c|c|c|c|}
\hline & $\begin{array}{c}\text { Tarihsel } \\
\text { Göçmenlik } \\
\text { Motivasyonu }\end{array}$ & $\begin{array}{c}\text { Aile } \\
\text { Birleşimi } \\
\text { Durumu }\end{array}$ & $\begin{array}{l}\text { Alman } \\
\text { Toplumu } \\
\text { Gözündeki } \\
\text { Konum } \\
\end{array}$ & Önemli Notlar /Detaylar \\
\hline Türkiye & $\begin{array}{c}\text { İşçi Göçü } \\
\text { (1960'lar ve } \\
\text { 1970'ler) }\end{array}$ & Yoğun & Olumsuz & $\begin{array}{l}\text { 1960'dan 1990'lara kadar devam eden } \\
\text { devamlı göç dalgasıyla Almanya'daki } \\
\text { en büyük göçmen topluluğu. }\end{array}$ \\
\hline $\begin{array}{l}\text { Güney } \\
\text { Avrupa }\end{array}$ & $\begin{array}{l}\text { İşçi Göçü } \\
\text { (1960’lar ve } \\
\text { 1970’ler) }\end{array}$ & Sinirlı & Olumlu & $\begin{array}{c}\text { Yunanistan, İtalya, Portekiz ve } \\
\text { İspanya'dan gelenler. İşçi göçüyle } \\
\text { gelmiş olsa da tarihsel yakınlıklardan } \\
\text { ötürü Almanya toplumuyla } \\
\text { kültürel olarak daha yakın bağları var. }\end{array}$ \\
\hline $\begin{array}{l}\text { Eski } \\
\text { Yugoslavya }\end{array}$ & $\begin{array}{l}\text { İşçi Göçü } \\
\text { (1960’lar ve } \\
\text { 1970'ler) }\end{array}$ & Sinırlı & $\begin{array}{c}\text { Sinırlı } \\
\text { Olumsuz }\end{array}$ & $\begin{array}{l}\text { Eski Yugoslav Cumhuriyetleri'nden } \\
\text { gelenler. Büyük çoğunluğu daha sonra } \\
\text { ülkelerine dönmüştür veya mevsimlik işçi } \\
\text { olarak çalışmaya devam etmiştir. }\end{array}$ \\
\hline Polonya & $\begin{array}{l}\text { Beyin Göçü } \\
\text { / Tarihsel } \\
\text { Yakınlık } \\
\text { (1990'lar } \\
\text { sonras1) }\end{array}$ & Yok & Nötr & $\begin{array}{l}\text { Göç edenler genelde yüksek öğrenim } \\
\text { mezunu oldukları için toplum } \\
\text { gözündeki konumları olumsuz değildir. } \\
\text { Ancak tarihsel olarak Almanya ve } \\
\text { Polonya'nın siyasi ve diplomatik } \\
\text { ilişkileri gergindir. }\end{array}$ \\
\hline $\begin{array}{l}\text { Eski } \\
\text { Sovyetler } \\
\text { Birliği }\end{array}$ & $\begin{array}{l}\text { Geriye Göç } \\
\text { (1990'lar) }\end{array}$ & Yok & Olumlu & $\begin{array}{l}\text { Geriye göç eden etnik Almanların } \\
\text { oluşturduğu bir grup için toplumdaki } \\
\text { konumları olumludur. Alman Devleti } \\
\text { tarafindan birçok olanak } \\
\text { kendilerine sağlanmıştır. }\end{array}$ \\
\hline $\begin{array}{l}\text { Diğer } \\
\text { Avrupa } \\
\text { Ülkeleri }\end{array}$ & $\begin{array}{l}\text { Beyin Göçü / } \\
\text { Geriye Göç } \\
\text { Batı Avrupa'dan } \\
\text { 1990'lar. Doğu } \\
\text { Avrupa'dan } \\
\text { 1950 ve } \\
\text { 1960'lar) }\end{array}$ & Yok & Olumlu & $\begin{array}{l}\text { Geriye kalan tüm Avrupa ülkeleri. } \\
\text { Doğu Avrupa'dan gelenler, } 1950 \text { ve } \\
\text { 1960'larda gelen, Batı Avrupa'dan } \\
\text { gelenler de çok eğitimli göçmenler } \\
\text { oldukları için, Alman toplumsal } \\
\text { hiyerarşisindeki konumları saygındır. }\end{array}$ \\
\hline
\end{tabular}

* Tablo 1, Kalter ve Granato (2007), Kogan (2011), Schulz ve Leszczensky (2016) ve

Wegmann'ın (2014) çalışmaları göz önünde bulundurularak yazar tarafından hazırlanmıştır.

tim ve beceri düzeylerini ölçmeye devam etmektedir. Bu çalışmada 5. ve 9 . sınıf öğrencilerinden oluşan iki farklı örneklemden yararlanılmıştır. 5. sınıf örneklemiyle ilgili veriler 2010-2015 yılları arasında yapılan 3 dalgadan, 9. Sınıf örneklemiyle ilgili veriler ise 2010-2011 yıllarında yapılan birinci dalga çalışmadan alınmıştır. 5. Sınıf örnekleminde göçmenlik durumu tespit edilebilen, Almanlar da dahil 5102 öğrenci yer almıştır. 9. Sınıf örnekleminde ise 13793 öğrenci yer almıştır. Bu anketlerde, öğrencilerin matematik, fen, oku- 
ma alanlarındaki başarı durumları sınıf ortamında, kâğıt ve kurşun kalem metoduyla (PAPI) ölçülmüş, ayrıca aileleri, ev yaşamları, mahalleleri ve eğitim ve gelecek planlarıyla ilgili bilgiler toplanmıştır. Göçmen geçmişi olan öğrencilerden ise, detaylı olarak göçmenlik durumları, göçmen olarak geldikleri ülkelerin dilini konuşup konuşamadıkları, kendilerini Alman toplumunun bir parçası hissedip hissetmedikleriyle ilgili bilgiler toplanmıştır. Nüfus sayımının ve diğer çalışmalarının aksine UEPA anketleri, öğrencilerden büyükanne ve büyükbabalarıyla ilgili bilgiler de toplanarak, üçüncü nesil göçmen olup olmadıklarını tespit edebilmiştir. Bu nedenle var olan asimilasyon kuramlarının öngörüleri çerçevesinde daha genç nesiller için bütünleşme sürecinin nasıl gerçekleştiği anlaşılabilmektedir.

UEPA örneklemleri, Türkiye geçmişli öğrencilerin başlıca eğitime erişim ve eğitim başarısını tartışmak için kullanılmıştır. Her iki örneklem de Almanya'daki 5. ve 9. Sınıf öğrencilerini ulusal düzeyde temsil etmektedir. Bu açıdan 5. Veya 9. Sınıftan önce okuldan ayrılmış grupları temsil edememektedir. Önceki çalışmalar, okul bırakma oranlarının Türkiyeli gençler arasında daha yüksek olduğunu göstermiştir ancak kesin bir rakam verebilmek mümkün değildir (Çelik, 2011).

Yöntem olarak öncelikle, bu makalede, Türkiyeli göçmen gençlerinin eğitim başarısını Alman ve diğer göçmen çocuklarıyla karşılaştırmalı olarak göstererek var olan eşitsizliklere yol açan faktörler olarak tartışılacaktır. Çalışmada Türkiyeli grubun karşılaştırıldığı göçmen gruplar, yukarıda kısaca tartışılan, Almanya'nın göç tarihi içinde önemli olan gruplardır. Tablo 1, bu göçmen gruplarını tarihsel göç hikayeleriyle ve bugün Alman toplumu gözündeki yeriyle açıklamaktadır. Bu gruplar bugün Almanya'daki toplam göçmen nüfusun \%85'ine tekabül etmektedir. Bunun dişındaki \% 15'lik grup içinde en kalabalık olan gruplar arasında Afrika, Ortadoğu ve Güney Doğu Asyalılar bulunmaktadır.

Güney Avrupalı ve eski Yugoslavyalı göçmenler de tıpkı Türkiyeli olanlar gibi göçmen işçi olarak Almanya'ya gelmeye başlamışlardır. Ancak sayıları hiçbir zaman Türkiyeliler'in seviyesine ulaşmamıştır. Eski Yugoslavyalılar daha yüksek oranlarda ülkelerine dönmüştür. Güney Avrupalılar arasında ise, Alman eşlerle evlenme oranı diğerlerine göre çok yüksektir (Haug, 2003). Bu yüzden aile birleşmesi bu gruplar arasında Türkiyeli göçmenlere nazaran çok sınırlıdır. 
Yukarıda da anlatıldığ gibi, eski Sovyetler Birliği'nden gelenler geriye göç eden Alman kökenliler olduğu için hem toplum hem de devletin gözünde müspet bir yerdedirler. (Ya da Alman kökenli oldukları düşünüldüğü için. Çünkü Alman hükümeti o dönemde sahte başvuru korkusuyla ilk dalgadan sonra bu tip göçmenlere daha sıkı başvuru şartları ve senelik kotalara sınırlamalar getirmiştir, bkz. Kalter ve Kogan, 2014.) Ancak yine de ailelerin eğitim durumları ve yeni göçmen olmaları sebebiyle göçmen gruplar arasında eski Yugoslavya asıllı öğrencilerle birlikte eğitim başarısı merdivenin aşağılarında yer alırlar. Polonyalı göçmenlerin durumu daha karmaşıktır. Her ne kadar eğitimli Polonyalılar Almanya'ya göç ediyor olsalar da Almanya ve Polonya devletleri arasındaki tarihsel husumet Polonyalı göçmenlerin Alman toplumundaki yerini anlamamız için biraz daha zaman geçmesi gerektiğine işaret etmektedir. Son olarak Diğer Avrupa olarak sınıflandırılan grup son derece iyi eğitimli ve beyaz yakalı çalışan ailelerdir ve Alman toplumsal sınıf ve kültürel hiyerarşisinin üst sıralarında yer alırlar.

Her ne kadar bu çalışma yalnızca Türkiye asıllı göçmenlerin durumuna eğiliyor olsa da göç mefhumunu Almanya özelinde bir tarihsel bağlama oturtmak gerekmektedir. Ayrıca, göçmenlere karşı tutumlar ve göçmenlerin kendilerini içinde buldukları ortam toplumsal ve kültürel bir ilişkisellikler ağı içerisinde gerçekleşmektedir. Bu yüzden aşağıdaki değerlendirmelerde Türkiye'den Almanya'ya göçmüş gençliğin durumu tartış1lırken Alman toplumumun $1 / 5$ 'ine tekabül eden bütün göçmen grupların durumlarına da göz atılacaktır.

\section{Ortaöğretime Yerleşme ve Ortaöğretim Başarısındaki Eşitsizlikler}

Almanya'da ortaöğretim sistemi birbirinden farklılaşmış okul tiplerine bölünmüştür. Bu okul tipleri hem müfredat hem de okul sonrası fırsatlar açısından oldukça sıkı bir hiyerarşi içerisindedir (Allmendinger, 1989). Herhangi bir okul tipine -özellikle de akademik olmayan düz liselere- yerleştikten sonra daha iyi bir okul tipine geçiş çok nadir olarak gerçekleşmektedir (Neugebauer vd., 2013). Bu okul yapısı son yıllarda değişikliğe uğramış olsa da örneklemden veri toplandığı dönemde ulusal ölçekte oldukça benzerlik göstermektedir.

Almanya'da ortaöğretime geçiş federal eyaletlerin çoğunluğunda 4. sınıftan sonra gerçekleşmektedir. İlkokul eğitiminden sonra öğrenciler üç temel okul tipinden birine yerleştirilmektedir. Bu okul tipleri okulda verilen müf- 
redatla yakından ilintilidir. Farklı okul tiplerine yerleşmek için öğretmen tavsiyeleri önemli bir adımdır ancak 16 federal eyaletin (Berlin şehri de kendi başına federal eyalet statüsündedir) 3'ünde öğretmen tavsiyelerinin bağlay1cılığı vardır. Diğer eyaletlerde öğrenciler ve veliler oturdukları yerlere göre diledikleri okul tiplerinden birini seçerler (Buchmann ve Park, 2009). Ancak göçmen ailelerin eğitim sistemine aşinalığının Alman ebeveynlerden daha az olacağını da göz önünde bulundurmak gerekir. Bu göçmen ailelerin öğretmenin tavsiyesine uyma ihtimalini artırmaktadır (bkz. Kao ve Tienda, 1998). Üç temel okul tipi şöyledir:

1. Gymnaisum (Akademik Lise): Üniversite ve uygulamalı bilimler yüksekokullarına geçişe olanak veren imtihana (Abitur) girme imkânı veren tek okul tipidir. 12. Sınıfa kadar eğitim vermektedir. Üniversiteye girmek için bu okullardan birinden mezun olmak şarttır.

2. Realschule (Orta Dereceli Lise): Genel genişletilmiş bir müfredata bağlıdır. Daha ziyade mesleki eğitime devam edecek öğrenciler bu okullardan gelmektedir. 10. Sınıfa kadar eğitim vermektedir. Düz liselerle birleştirildikleri için sayıları gün geçtikçe azalmaktadır.

3. Hauptschule (Düz Lise): Temel zorunlu lise eğitiminin verildiği liselerdir. Bu liseden mezun olanlar ne üniversitelere ne de meslek yüksek eğitimine devam edebilirler. Eğitim sosyolojisi yazınında “çıkmaz sokak” olarak nitelendirilirler.

Bu üç temel okul tipi dişında, yukarıda sayılanlar arasından iki veya üç temel müfredatı aynı okul çatısı altında sunan "genel liseler" (Gesamtschule ve Schhlen mit mehrere Bildungsgaengen) de mevcuttur. Tablo 2 ve 3 'teki "Diğer Liseler" grubu bu iki lise tipini kapsamaktadır. Genel liselerin yarısında akademik müfredat sınıfları bulunmaz. 2012 yılından itibaren genel liselerin sayısı neredeyse iki katına çıkmıştır (Maaz vd., 2016, S. 73), ancak bu genişlemenin sonuçlarını inceleme imkânı henüz doğmamıştır.

Türkiye asıllı öğrencilerin eğitim alanındaki eşitsizliği daha 4. sınıf sonunda gerçekleşen yerleştirme sürecinden itibaren başlamaktadır. Tablo 2 ve Tablo 3 'te UEPA 5. Ve 9. sınıf örneklemlerinde yer alan öğrencilerin göçmenlik durumuna ve okul tipine göre dağılımını göstermektedir. Görüldüğü üzere, her iki örneklemde de öğrencilerin 10 öğrenciden en az 3'ü göçmen kökenlidir. Yaş küçüldükçe göçmenlerin nüfusa oranının arttığını gösteren nüfus 
sayımı rakamlarına paralel olarak, 5. sınıf öğrencilerinin \%35'inin göçmen kökenli olduğu görünmektedir.

Türkiyeliler, her iki örneklemde de toplam nüfusun \%6'sını temsil etmektedirler.

Tablo 2

Alman ve göçmen geçisi olan ögrrencilerin devam ettiği ortaöğretim okul tipi (9. Sinı örneklemi) Alman Türkiye Güney Eski Polonya Eski Diğer Diğer Toplam Avrupa Yugoslavya

\begin{tabular}{lccccccccc}
\hline Düz Lise & 2,044 & 409 & 192 & 165 & 93 & 293 & 177 & 109 & 3,482 \\
(Hauptschule) & $(20 \%)$ & $(48 \%)$ & $(41 \%)$ & $(40 \%)$ & $(21 \%)$ & $(41 \%)$ & $(17 \%)$ & $(30 \%)$ & $(25 \%)$ \\
Orta Derece & 2,200 & 152 & 93 & 90 & 99 & 170 & 186 & 58 & 3,048 \\
(Realschule) & $(22 \%)$ & $(18 \%)$ & $(20 \%)$ & $(22 \%)$ & $(22 \%)$ & $(24 \%)$ & $(22 \%)$ & $(16 \%)$ & $(22 \%)$ \\
Akademik Lise & 3,820 & 146 & 116 & 99 & 137 & 145 & 369 & 132 & 4,964 \\
(Gymnasium) & $(38 \%)$ & $(17 \%)$ & $(25 \%)$ & $(24 \%)$ & $(31 \%)$ & $(20 \%)$ & $(43 \%)$ & $(36 \%)$ & $(35 \%)$ \\
Diğer Lise & 1,976 & 140 & 70 & 62 & 117 & 111 & 122 & 70 & 2,668 \\
& $(20 \%)$ & $(17 \%)$ & $(15 \%)$ & $(15 \%)$ & $(26 \%)$ & $(15 \%)$ & $(14 \%)$ & $(19 \%)$ & $(19 \%)$ \\
Toplam & 10,040 & 847 & 471 & 416 & 446 & 719 & 854 & 369 & 13793 \\
& $(73 \%)$ & $(6 \%)$ & $(3.4 \%)$ & $(3 \%)$ & $(3.2 \%)$ & $(5.2 \%)$ & $(6.2 \%)$ & $(3 \%)$ & $(100 \%)$ \\
\hline
\end{tabular}

Kaynak: Ulusal Eğitim Paneli Araştırması 9. Sınıf Örneklemi (2011)

Tablo 3

Alman ve göçmen geçiși olan ögrencilerin devam ettiği ortaöğretim okul tipi (5. Sinı örneklemi) Alman Türkiye Güney Eski Polonya Eski Diğer Diğer Toplam Avrupa Yugoslavya SSCB Avrupa

\begin{tabular}{lccccccccc}
\hline Düz Lise & 416 & 65 & 28 & 36 & 25 & 58 & 22 & 79 & 729 \\
(Hauptschule) & $(12 \%)$ & $(20 \%)$ & $(18 \%)$ & $(25 \%)$ & $(14 \%)$ & $(23 \%)$ & $(8 \%)$ & $(19 \%)$ & $(14 \%)$ \\
Orta Derece & 763 & 84 & 33 & 40 & 34 & 58 & 62 & 77 & 1,151 \\
(Realschule) & $(23 \%)$ & $(26 \%)$ & $(21 \%)$ & $(28 \%)$ & $(19 \%)$ & $(23 \%)$ & $(24 \%)$ & $(19 \%)$ & $(23 \%)$ \\
Akademik Lise & 1,632 & 83 & 82 & 52 & 90 & 112 & 153 & 185 & 2,389 \\
(Gymnasium) & $(49 \%)$ & $(26 \%)$ & $(52 \%)$ & $(36 \%)$ & $(49 \%)$ & $(43 \%)$ & $(58 \%)$ & $(45 \%)$ & $(47 \%)$ \\
Diğer Lise & 551 & 91 & 16 & 15 & 35 & 30 & 25 & 70 & 833 \\
& $(17 \%)$ & $(28 \%)$ & $(10 \%)$ & $(11 \%)$ & $(19 \%)$ & $(12 \%)$ & $(10 \%)$ & $(17 \%)$ & $(16 \%)$ \\
Toplam & 3,362 & 323 & 159 & 143 & 184 & 258 & 262 & 411 & 5102 \\
& $(65 \%)$ & $(6.3 \%)$ & $(3 \%)$ & $(3 \%)$ & $(3.6 \%)$ & $(5 \%)$ & $(5 \%)$ & $(8 \%)$ & $(100 \%)$ \\
\hline
\end{tabular}

Kaynak: Ulusal Eğitim Paneli Araştırması 5. Sınıf Örneklemi (2016)

1960’larda işçi göçüyle gelmeye başlayan diğer iki önemli grup -Güney Avrupalılar ve eski Yugoslavyalılar- örneklemlerin \%3’üne, Polonyalılar da örneklemlerin \%3’üne denk gelmektedirler. Bir diğer önemli göçmen grubu olan eski SSCB'den göçenler ise

örneklemlerin \%5'ine tekabül etmektedirler. Göçmen grupların kendi içindeki dağılımları ulusal ölçekteki göçmen nüfuslarıyla örtüşmektedir.

Alman ve göçmen geçmişli öğrencilerin okul tipine göre dağılımı gösteriyor ki, Türkiyeli öğrenciler her iki örneklemde de akademik liseye en az oranda devam eden grubu oluşturmaktadır. Bu da demek oluyor ki, lise sonunda 
üniversiteye girme şansına en az sahip olan grup Türkiye asıllı öğrenciler olacaktır. Benzer şekilde, 9. sınıf örnekleminde Türkiye asıllı öğrencilerin yarısına yakını düz liseye devam etmektedir. 5. sınıf örnekleminde ise bu grup, eski SSCB ve eski Yugoslavya asıllılarla beraber en yüksek oranda düz liseye devam etmektedir. Okul tipi dağılımına göre, Türkiye asıllı öğrenciler Alman ve Avrupalı akranlarının oldukça gerisindedir.

Daha da önemlisi işçi göçüyle gelmiş diğer toplulukların çocuklarının Güney Avrupalılar ve eski Yugoslavyalılar- ve de eski SSCB gibi henüz göçmenlik tarihi açısından Almanya'da yeni sayılabilecek bir grubun dahi gerisinde kalmaktadırlar.

Okul tipi dışında, öğrencilerin 5. ve 9. sınıftaki okuma ve matematik becerileri de gruplar arasında büyük farkl1lıklar arz etmektedir. Her ne kadar okuma ve matematik becerilerinin başlica belirleyeni okul tipi olsa da Alman öğrenciler ve göçmen gruplarının kendi aralarındaki ortalamaları da eğitim başarısı açısından önemli faktörlerdir. Şekil 1 ve Şekil 2'de sırasıyla Alman ve göçmen geçmişli öğrencilerin okuma ve matematik başarı ortalamaları gösterilmiştir. Bu skorlar UEPA veri seti tarafindan sağlanan standardize edilmiş ağırlıklı puanlardır. Dağılımların ortalaması 0, standart sapmaları 1'dir.

Şekil 1 ve Şekil 2, 5. ve 9. sınıf örneklemlerinin okuma puanlarının, Alman ve göçmen geçmişli öğrenci gruplarına göre dağılımını göstermektedir. Şekil 1 'de verilen 9. sınıf okuma puanı dağılımına göre sadece Alman ve Diğer Avrupa grubu 0 üzerinde bir ortalama puana sahiptir. Türkiye asıllı öğrenciler tüm gruplar arasında en düşük puana sahiptirler ve ortalama olarak Alman akranlarından tam bir standart sapma geridedirler. Bu gruptan sonra en başarısız iki grup olan eski Yugoslavya ve eski SSCB ülkelerinden göç etmiş çocuklar dahi, Türkiyeli öğrencilerden yarım standart sapma daha yüksek bir okuma ortalamasına sahiptirler. Güney Avrupa ve Polonya asıllı öğrenciler ise orta düzeyde bir okuma puanı tutturmuş görünmektelerdir. Öte yandan, pozitif uçdeğerlerin en fazla Türkiye asıllı öğrencilerde görülmesi de önemlidir. Bunun iki olası sebebi vardır: bu öğrenciler ailelerinin yakından ilgi göstererek eğitimleriyle yakından ilgilendiği bir gruptur veya bu öğrencilerin ebeveynlerinden bir tanesi Almandır ve evde öğrendiği dil becerisi yüzünden Almanca öğrenme konusunda bir sıkıntı yaşamayan bir azınlığı temsil etmektedirler. 
Benzer bir dağılım 5. sınıf örneklemi için de geçerlidir. Yine Alman ve Diğer Avrupa grupları en yüksek okuma puanına ulaşan gruplar olmuş, Türkiye asıllı ögrenciler ise dağılımın en sonunda yer almaktadırlar. Eski Yugoslavya, eski SSCB ve Polonya asıllı göçmen öğrenciler ise Türkiyeli grubun hemen yukarısında yer almaktadırlar.

Güney Avrupalı grup ise işçi göçmeni gruplar arasında en başarılı olandır. Bunun hem kültürel yakınlık hem de Güney Avrupalı göçmenlerin Almanlarla evlenme sıklığıyla yakından ilgisi vardır. Bu nedenlerden ötürü, Güney Avrupalı öğrenciler diğer işçi göçmenlerinin yeni nesil çocuklarının çektiği sıkıntılardan biraz olsun azade kalabilmişlerdir.

Benzer bir dağılım 9. sınıf örnekleminin matematik puanlarında görülmektedir. Alman ve Diğer Avrupalı göçmenler en başarılı gruplar olmaya devam etmektedir. Hemen arkalarında Güney Avrupa ve Polonyalı gruplar, onların arkalarında da eski Yugoslavya ve eski SSCB'den gelen öğrenciler yer almaktadır. Okuma puanlarında olduğu gibi, matematik alanında da en başarısız grup Türkiyeli öğrenciler olarak öne çıkmaktadır. Okuma alanından farklı olarak, Türkiyeli öğrenciler matematik puanında Alman ve diğer akranlarına daha yakın bir ortalama puan almışlardır.

UEPA'nın panel çalışması özelliğinden faydalanılarak başarı puanlarının zaman içinde değişimini incelemek de mümkün olmaktadır. Şekil 4, 5. sınıf örnekleminin okuma puanının 5. sınıftan 9. sınıfa kadar olan değişimini göstermektedir. Görüldüğü üzere, Türkiyeli öğrencilerin ortalama başarı puanı 5 . sınıfta hem Alman hem de diğer göçmen öğrencilerin bir ile yarım standart sapma arasında gerisindedir. Bu fark yalnızca 2014-2015 ölçümünde çok küçük bir oranda azalmıştır. Ortaöğretimin başında, 5. sınıfta, Türkiyeli öğrencilerin aleyhine olan Almanca okuma alanındaki durum, 9. sınıfa kadar devam etmekte ve onların üniversiteye giriş fırsatlarına da olumsuz etki yapmaktadır.

Özetle hem akademik lise tipine yerleşme hem de ortaöğretim sürecinde okuma ve matematik puanları açısından Türkiye asıllı öğrenciler en dezavantajlı grup olarak öne çıkmaktadırlar. Bu dezavantajların 2000'lerin sonrasında doğmuş 5. sınıf örnekleminde dahi gözlemlenebiliyor olması, bu sorunların Türkiye'den Almanya'ya göçün başlamasından 50 yıldan fazla sonra bile geçerliliğini koruduğunu göstermektedir. Türkiyeli gençlik için eğitime erişim, 
ortaöğretim sonrası üniversiteye giriş firsatları ve bunun sonrasında gerçekleşecek işgücüne katılım alanlarında yapısal anlamda derin bir eşitsizlik yaşamaya devam etmektedir. Daha da önemlisi, daha genç nesiller için bu eşitsizlikler yeniden üretilmektedir. Başka bir ifadeyle, bazı göçmen grupların genç nesilleri Alman akranlarına yaklaşırken, Türkiyeli toplum için bu eşitsizlikler yeni nesillere aktarılmaktadır.

Şekil 1

Alman ve göçmen geçmişli grupların okuma puanı dağılımı (9. Sınıf)

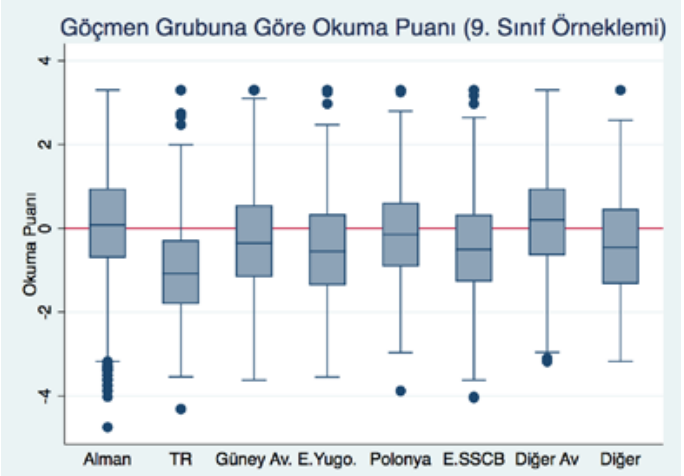

Kaynak: Ulusal Eğitim Paneli Araştırması 9. Sınıf Örneklemi (2011) Şekil 2

Alman ve göçmen geçmişli grupların okuma puanı dağılımı (5. Sinıf)

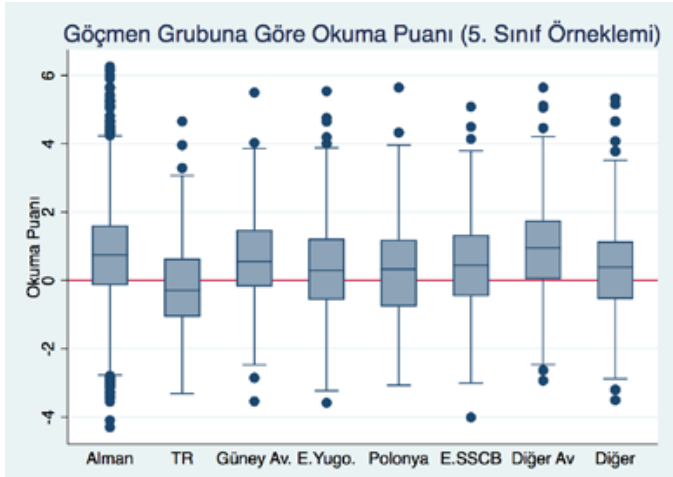

Kaynak: Ulusal Eğitim Paneli Araştırması 5. Sınıf Örneklemi (2011) 


\section{Şekil 3}

Alman ve göçmen geçmişli grupların matematik puanı dă̆ılımı (9. Sınıf)

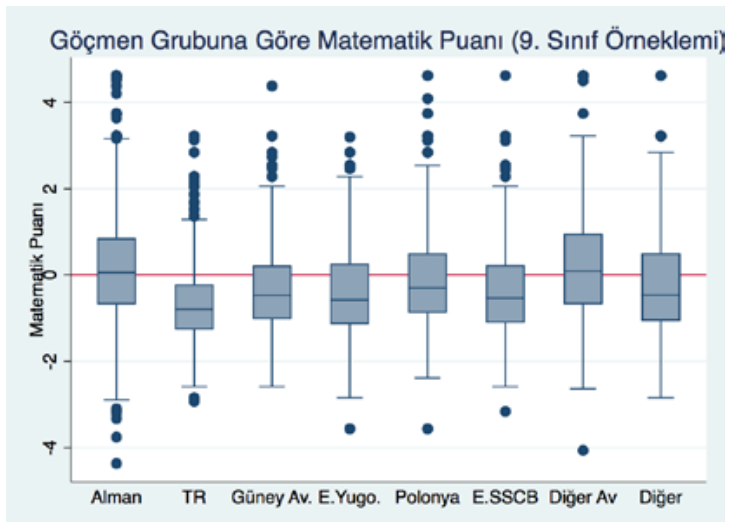

Kaynak: Ulusal Eğitim Paneli Araştırması 9. Sınıf Örneklemi (2011)

Şekil 4

Alman ve göçmen geçmişli grupların okuma puanının zaman içindeki değişimi (5. Sinıf örneklemi)

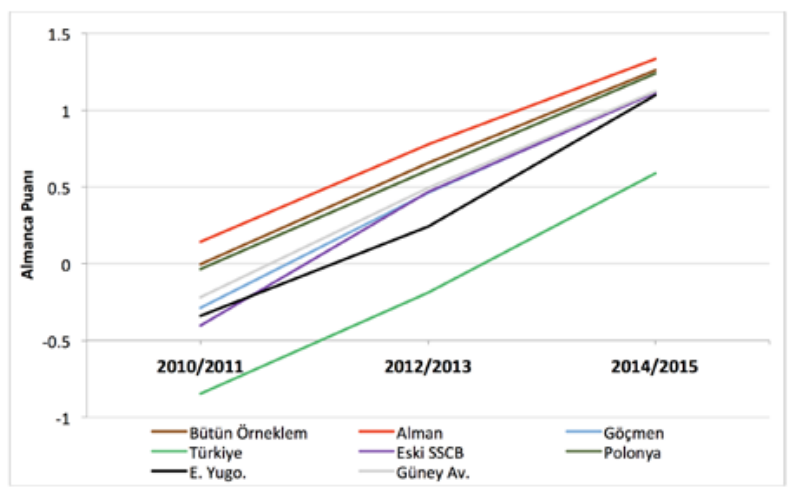

Kaynak: Ulusal Eğitim Paneli Araştırması 5. Sınıf Örneklemi (2016)

\section{Eğitim Eşitsizliklerinin Arkasındaki Nedenler}

Bu bölümde Türkiyeli topluluğun yaşadığı eğitim eşitsizliklerinin arkasındaki olası faktörler ele alınacaktır. Kavramsal çerçeve tartışması izleğinde, bu faktörleri üç ana başlık altında toplamak mümkündür:

1. Ailenin Eğitim Durumu ve Sosyoekonomik Statüsü

2. Almanca Kullanımı ve Arkadaşlık Bağları

3. İkamete Dayalı Tecrit 
Çalışmanın geri kalanında, Almanya'daki Türkiye asıllı göçmen genç nüfus göz önünde bulundurularak bu üç etmenler betimsel olarak incelenecektir. Görüleceği üzere Türkiye asıllı gençlik için var olan yapısal dezavantajlar yalnızca bir nedene bağlı değildir, bilakis birden çok faktörün bu durumun oluşmasına katkısı vardır. Kullanılan bilgiler UEPA 5. ve 9. sınıf örneklemlerinden alınmıştır. Ancak 9. sınıf soru kağıdında daha detaylı bilgiler toplandığından, bazı bilgiler sadece bu örneklemden toplanan bilgilere dayanmaktadır.

\section{Ailenin Eğitim Durumu ve Sosyoekonomik Statüsü}

Yukarıda da değinildiği gibi ebeveynlerin eğitimin durumu öğrencinin eğitim başarısı ve eğitim düzeyinde tayin edici bir rolü vardır. UEPA 9. sınıf örneklemine göre her 4 Türkiyeli öğrenciden birinin annesinin herhangi bir formel eğitimi yoktur (Skopek vd., 2013). Bu, okuma yazma bilinmediği anlamına gelmez ancak hiç okula gitmeme oranı Türkiyeli göçmenler arasında ürkütücü şekilde yüksektir. Buna paralel olarak, akademik lise veya dengi bir okul veya üniversite mezunlarının oranı Türkiyeli ebeveynler arasında diğer gruplarla karşılaştırılamayacak kadar azdır. Bu iki tip diplomaya sahip olan annelerin oranı Türkiyeli öğrenciler arasında \%10'u ancak geçerken, diğer hiçbir grupta bu oran \%24'ün altına inmemektedir.

UEPA 5. sınıf örneklemi için ise anne ve babanın ortalama öğrenim görme y1lı bilgisi bulunmaktadır (Skopek vd., 2013). Eğitim durumu kadar ailenin ortalama öğrenim görme yılı da öğrencilerin eğitim başarısı ve fırsatları için önemli bir belirleyendir. Bu veride herhangi bir ebeveynin bilgisinin eksik olması durumunda diğer ebeveyninki kıstas alınmıştır. 5. sınıf örnekleminde Türkiyeli göçmen asıllı öğrencilerin ebeveynlerinin ortalama öğretim yılı 10,33'tür. Bu rakam, örneklemin genel ortalamasından 3 yıl kısa, Alman akranlarının ebeveynlerinin ortalamasından neredeyse 4 yıl kısadır. Türkiyeli öğrenciler, ebeveynlerin ortalama öğrenim y1lı da göz önünde bulundurulduğunda göçmen asıllı öğrenciler arasında en alt sırada yer almaktadırlar.

Toplumsal tabakalaşama ve eğitim sosyolojisi yazınına göre, öğrencilerin evlerinde bulunan kitap sayısı da akademik başarının önemli bir belirleyenidir (Ammermüller, 2005). UEPA soru kağıdında, evdeki kitap sayısı değişkeni, doğrudan sayısını sormaktan ziyade, kitapların kapladığı raf ve raf seti üzerinden sorulup, kitap sayıları parantez içinde verilmiştir. Bu yüzden öğrencilerin 
Tablo 4

Ögrencilerinin evlerinde bulunan kitap sayısı (9. Sinı örneklemi)

Alman Türkiye Güney Eski Polonya Eski Diğer Diğer Toplam Avrupa Yugoslavya

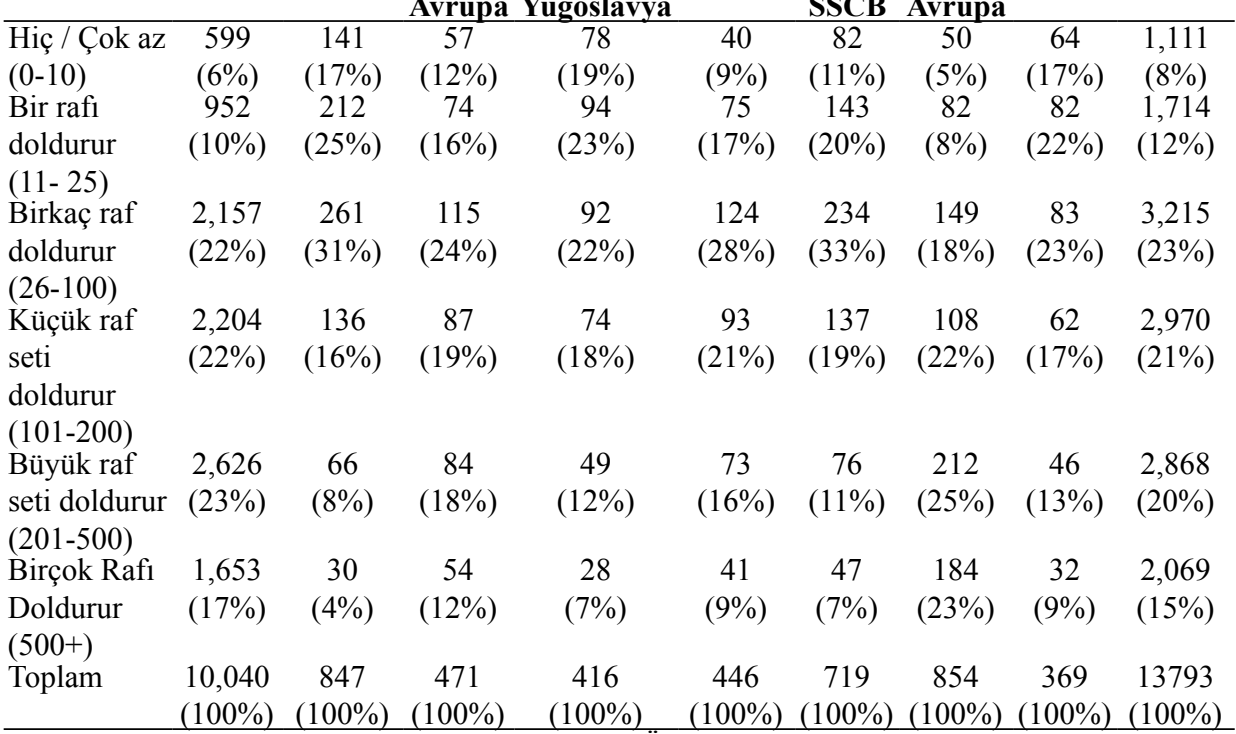

Kaynak: Ulusal Eğitim Paneli Araştırması 9. Sınıf Örneklemi (2011)

Tablo 5

Öğrencilerinin evlerinde bulunan kitap sayısı (5. Sinıf örneklemi)

Alman Türkiye Güney Eski Polonya Eski Diğer Diğer Toplam Avrupa Yugoslavya SSCB Avrupa

\begin{tabular}{|c|c|c|c|c|c|c|c|c|c|}
\hline $\begin{array}{l}\text { Hiç / Çok az } \\
(0-10) \\
\text { Bir rafi } \\
\text { doldurur }\end{array}$ & $\begin{array}{c}89 \\
(3 \%) \\
304 \\
(9 \%)\end{array}$ & $\begin{array}{c}35 \\
(11 \%) \\
71 \\
(23 \%)\end{array}$ & $\begin{array}{c}8 \\
(5 \%) \\
14 \\
(9 \%)\end{array}$ & $\begin{array}{c}14 \\
(10 \%) \\
24 \\
(17 \%)\end{array}$ & $\begin{array}{c}6 \\
(3 \%) \\
18 \\
(10 \%)\end{array}$ & $\begin{array}{c}26 \\
(10 \%) \\
42 \\
(16 \%)\end{array}$ & $\begin{array}{c}3 \\
(1 \%) \\
16 \\
(6 \%)\end{array}$ & $\begin{array}{c}31 \\
(8 \%) \\
62 \\
(15 \%)\end{array}$ & $\begin{array}{c}212 \\
(4 \%) \\
551 \\
(11 \%)\end{array}$ \\
\hline $\begin{array}{l}\text { irkaç raf } \\
\text { oldurur } \\
26-100)\end{array}$ & $\begin{array}{c}697 \\
(21 \%)\end{array}$ & $\begin{array}{c}110 \\
(35 \%)\end{array}$ & $\begin{array}{c}44 \\
(28 \%)\end{array}$ & $\begin{array}{c}47 \\
(33 \%)\end{array}$ & $\begin{array}{c}39 \\
(22 \%)\end{array}$ & $\begin{array}{c}77 \\
(30 \%)\end{array}$ & $\begin{array}{c}51 \\
(20 \%)\end{array}$ & $\begin{array}{c}89 \\
(22 \%)\end{array}$ & $\begin{array}{c}1154 \\
(23 \%)\end{array}$ \\
\hline $\begin{array}{l}\text { üçük raf } \\
\text { eti } \\
\text { oldurur } \\
101-200 \text { ) }\end{array}$ & $\begin{array}{c}736 \\
(22 \%)\end{array}$ & $\begin{array}{c}64 \\
(20 \%)\end{array}$ & $\begin{array}{c}35 \\
(23 \%)\end{array}$ & $\begin{array}{c}28 \\
(20 \%)\end{array}$ & $\begin{array}{c}47 \\
(26 \%)\end{array}$ & $\begin{array}{c}58 \\
(23 \%)\end{array}$ & $\begin{array}{c}53 \\
(20 \%)\end{array}$ & $\begin{array}{c}95 \\
(23 \%)\end{array}$ & $\begin{array}{c}1116 \\
(22 \%)\end{array}$ \\
\hline $\begin{array}{l}\text { üyük raf } \\
\text { eti doldurur }\end{array}$ & $\begin{array}{c}829 \\
(25 \%)\end{array}$ & $\begin{array}{c}23 \\
(7 \%)\end{array}$ & $\begin{array}{c}36 \\
(23 \%)\end{array}$ & $\begin{array}{c}16 \\
(11 \%)\end{array}$ & $\begin{array}{c}45 \\
(25 \%)\end{array}$ & $\begin{array}{c}33 \\
(13 \%)\end{array}$ & $\begin{array}{c}74 \\
(29 \%)\end{array}$ & $\begin{array}{c}77 \\
(19 \%)\end{array}$ & $\begin{array}{c}1133 \\
(22 \%)\end{array}$ \\
\hline $\begin{array}{l}\text { irçok Rafi } \\
\text { oldurur } \\
500+)\end{array}$ & $\begin{array}{c}691 \\
(21 \%)\end{array}$ & $\begin{array}{c}11 \\
(4 \%)\end{array}$ & $\begin{array}{c}18 \\
(12 \%)\end{array}$ & $\begin{array}{c}14 \\
(10 \%)\end{array}$ & $\begin{array}{c}26 \\
(14 \%)\end{array}$ & $\begin{array}{c}21 \\
(8 \%)\end{array}$ & $\begin{array}{c}63 \\
(24 \%)\end{array}$ & $\begin{array}{c}53 \\
(13 \%)\end{array}$ & $\begin{array}{c}897 \\
(18 \%)\end{array}$ \\
\hline oplam & $\begin{array}{c}3,362 \\
(100 \%)\end{array}$ & $\begin{array}{c}323 \\
100 \%) \\
\end{array}$ & $\begin{array}{c}159 \\
100 \%) \\
\end{array}$ & $\begin{array}{c}143 \\
(100 \%)\end{array}$ & $\begin{array}{c}184 \\
(100 \%)\end{array}$ & $\begin{array}{c}258 \\
100 \%) \\
\end{array}$ & $\begin{array}{c}262 \\
(100 \%)\end{array}$ & $\begin{array}{c}411 \\
(100 \%)\end{array}$ & $\begin{array}{c}5102 \\
(100 \%)\end{array}$ \\
\hline
\end{tabular}

Kaynak: Ulusal Eğitim Paneli Araştırması 5. Sınıf Örneklemi (2016) 
sorulara verdikleri cevaplar sahih olarak kabul edilebilir. Tablo 4 ve Tablo 5 'te her iki örneklem için de evde bulunan kitap sayısı dağılımı her iki örneklem için de Türkiyeli asıllı öğrenciler için en düşük düzeydedir. Evdeki kitap say1sına 201-500 veya 500+ cevabını veren öğrenciler Türkiyeliler arasında \%10 civarındadır. Bu oranlar Alman ve Avrupalı göçmenler için

\%50'ye dayanmaktadır. En az sayıda kitap bulunan evlerin oranı da Türkiyeli, eski Yugoslavya ve eski SSCB asıllı öğrenciler arasında en yüksektir.

Ortaöğretimdeki başarı seviyesiyle paralel olarak, ailenin eğitim durumu ve evde bulunan kitap sayısı gibi önemli faktörlerde, başta Türkiye ası1lı öğrenciler olmak üzere, eski Yugoslavya ve eski SSCB'den öğrenciler hiyerarşinin en alt sıralarında yer almaktadır. Ancak yukarıda tartışıldığ 1 gibi, bu sosyoekonomik faktörler dışında da eğitim başarısı ve firsatlarını belirleyici olabilecek başka değişkenler de mevcuttur. Çalışmanın geri kalanında bu faktörler tartışılacaktır.

\section{Almanca Kullanımı ve Arkadaşlık Bağları}

Ailenin eğitim ve sosyoekonomik durumu dışında göçmen asıllıların eğitim başarısını belirleyenen önemli faktörlerden bir tanesi de dil becerisidir. Yukarıda gördügüümüz gibi Türkiye asıllı göçmenler özellikle okuma alanında Alman akranlarının gerisinde kalmaktadırlar. Bu yüzden öncelikle göçmen çocuklarının Almanca diline aşinalığını irdelemek önemlidir. Bu aşamada Alman öğrencilerin dille ilişkisi önemli olmadığından sadece göçmen geçmişli öğrencilerin dağılımları incelenecektir.

Tablo 6, 9. sınıf örneklemindeki göçmen asıllı öğrencilerin anne-babalarının evde birbirleriyle konuştukları dili göstermektedir. UEPA'ya göre bu bilginin kaynağı anketi dolduran öğrencidir. Yani anne-babalar kendi aralarında hangi dili konuştuklarını yazmaktan ziyade, öğrenciler duydukları üzerinden anne-babanın hangi dili konuştuklarını aktarmaktadır.

Görüldüğü gibi, Türkiye ve eski SSCB asıllı öğrencilerin ebeveynlerinin çok küçük bir kısmı kendi aralarında Almanca konuşmaktadırlar. Aynı grupların önemli bir kesimi de evde sırasıyla Türkçe ve Rusça konuşmaktadırlar. Alman toplumuyla daha fazla bütünleşmiş olan Avrupalı göçmen gruplara bakıldığında ise ebeveynlerinin çoğunluğu kendi aralarında Almanca konuş- 
maktadırlar. Evde işitilen ve öğrenilen dilin, öğrencilerin dil becerileri ve okuma başarısıyla yakından ilişkisi olduğu göz önünde bulundurulduğunda, evde konuşulan Türkçe'nin Türkiye asıllı öğrencilerin lise hayatına olumsuz yansıdığı açıktır. Diğer bir ifadeyle, okul yaşamında okumayla ilgili yaşanan sıkıntılar, evde Almanca konuşmanın noksanlığıyla da ilgilidir.

En yakın arkadaşla konuşulan dile bakıldığında, Türkiyeli öğrencilerin önemli bir çoğunluğunun "sadece Almanca" veya "çoğunlukla Almanca" konuştukları görülmektedir (Tablo 7). Bu açıdan ev içinde ebeveynlerin birbiriyle konuştukları dile nazaran daha sıklıkla Almanca kullandıkları söylenebilir. Ancak yine de "sadece Almanca" seçeneğinin oranı, eski SSCB asıllılar hariç tüm diğer grupların çok gerisindedir (\%46). Ayrıca, çoğunlukla Almanca konuşanların, "bazen de kendi geldikleri ülkenin anadilini konuşması" Türkiyeli öğrencilerin önemli bir bölümünün en yakın arkadaşlarının da Türkiye asıllı olduğunu göstermektedir. Kendi Alman akranlarıyla bütünleşme oranının en düşük olduğu grupların da Türkiye ve onları takiben de eski SSCB asıllı öğrenciler olduğu görülmektedir.

Tablo 6'da görüldüğü üzere Türkiyeli öğrencilerin ebeveynlerinin birbiriyle konuştukları dil ağırlıklı olarak Türkçe' dir. Tablo 7'ye göreyse kendi akran-

Tablo 6

Göcmen geçmișli ögrencilerinin ebeveynlerinin birbirleriyle konuștukları dil (9. Sinıf örneklemi)

\begin{tabular}{|c|c|c|c|c|c|c|c|c|}
\hline & Türkiye & $\begin{array}{c}\text { Güney } \\
\text { Avrupa }\end{array}$ & $\begin{array}{c}\text { Eski } \\
\text { Yugoslavya }\end{array}$ & Polonya & $\begin{array}{c}\text { Eski } \\
\text { SSCB }\end{array}$ & $\begin{array}{c}\text { Diğer } \\
\text { Avrupa }\end{array}$ & Diğer & Toplam \\
\hline Sadece & 86 & 243 & 143 & 195 & 85 & 568 & 79 & 1399 \\
\hline Almanca & $(10 \%)$ & $(52 \%)$ & $(34 \%)$ & $(44 \%)$ & $(12 \%)$ & $(67 \%)$ & $(21 \%)$ & $(34 \%)$ \\
\hline Çoğunlukla & 80 & 54 & 35 & 45 & 80 & 103 & 32 & 429 \\
\hline $\begin{array}{l}\text { Almanca } \\
\text { (Bazen kendi } \\
\text { anadilim) }\end{array}$ & $(10 \%)$ & $(12 \%)$ & $(8 \%)$ & $(10 \%)$ & $(11 \%)$ & $(12 \%)$ & $(9 \%)$ & $(10 \%)$ \\
\hline Çoğunlukla & 173 & 64 & 75 & 74 & 168 & 80 & 65 & 699 \\
\hline $\begin{array}{l}\text { Geldiğimiz } \\
\text { Ülkenin Dili }\end{array}$ & $(20 \%)$ & $(14 \%)$ & $(18 \%)$ & $(17 \%)$ & $(23 \%)$ & $(9 \%)$ & $(18 \%)$ & $(17 \%)$ \\
\hline $\begin{array}{l}\text { Sadece Geldi- } \\
\text { ğimiz } \\
\text { Ülkenin Dili }\end{array}$ & $\begin{array}{c}460 \\
(54 \%)\end{array}$ & $\begin{array}{c}91 \\
(19 \%)\end{array}$ & $\begin{array}{c}141 \\
(34 \%)\end{array}$ & $\begin{array}{c}112 \\
(25 \%)\end{array}$ & $\begin{array}{c}336 \\
(47 \%)\end{array}$ & $\begin{array}{c}84 \\
(10 \%)\end{array}$ & $\begin{array}{c}173 \\
(47 \%)\end{array}$ & $\begin{array}{l}1397 \\
(34 \%)\end{array}$ \\
\hline $\begin{array}{l}\text { Benim İçin } \\
\text { Geçerli Bir }\end{array}$ & $\begin{array}{c}44 \\
(5 \%)\end{array}$ & $\begin{array}{c}17 \\
(4 \%)\end{array}$ & $\begin{array}{c}16 \\
(4 \%)\end{array}$ & $\begin{array}{c}17 \\
(4 \%)\end{array}$ & $\begin{array}{c}48 \\
(7 \%)\end{array}$ & $\begin{array}{c}13 \\
(2 \%)\end{array}$ & $\begin{array}{c}14 \\
(4 \%)\end{array}$ & $\begin{array}{c}169 \\
(4 \%)\end{array}$ \\
\hline $\begin{array}{l}\text { Soru Değil } \\
\text { Eksik/Boş } \\
\text { Bırakmış } \\
\text { (Missing) }\end{array}$ & $\begin{array}{c}4 \\
(0 \%)\end{array}$ & $\begin{array}{c}2 \\
(0 \%)\end{array}$ & $\begin{array}{c}6 \\
(1 \%)\end{array}$ & $\begin{array}{c}3 \\
(1 \%)\end{array}$ & $\begin{array}{c}2 \\
(0 \%)\end{array}$ & $\begin{array}{c}6 \\
(1 \%)\end{array}$ & $\begin{array}{c}6 \\
(2 \%)\end{array}$ & $\begin{array}{c}29 \\
(1 \%)\end{array}$ \\
\hline Toplam & $\begin{array}{c}847 \\
(100 \%) \\
\end{array}$ & $\begin{array}{c}471 \\
(100 \%) \\
\end{array}$ & $\begin{array}{c}416 \\
(100 \%)\end{array}$ & $\begin{array}{c}446 \\
(100 \%) \\
\end{array}$ & $\begin{array}{c}719 \\
(100 \%) \\
\end{array}$ & $\begin{array}{c}854 \\
(100 \%) \\
\end{array}$ & $\begin{array}{c}369 \\
(100 \%) \\
\end{array}$ & $\begin{array}{c}4122 \\
(100 \%) \\
\end{array}$ \\
\hline
\end{tabular}

Kaynak: Ulusal Eğitim Paneli Araştırmas1 9. Sınıf Örneklemi (2011) 
larıyla Almanca kullanımı en az olan grup da Türkiyeli öğrencilerdir. Bunun Almanca becerilerisinin gelişmesini engellediğini söylemek abartı olmaz. Almanca dilinde becerinin Türkiye asıllı gençliğin en önemli problemlerinden biri olmaya devam etmesinin önemli sebeplerinden biri de budur.

Bu aşamada bakılması gerekilen bir diğer etken de göçmen geçmişi olan gençlerin arkadaş çevreleridir. Toplumla bütünleşememiş ve etnik olarak tecrit edilmiş mahallelerde ikamet eden göçmen gruplar ve onların çocukları için yerli gruba mensup akranlarıyla arkadaşlık ilişkileri kurmak ve yerli ağlara dahil olabilmek güçtür. Buna müteakip,

Tablo 7

Göçmen geçmișli öğrencilerinin en yakın arkadașlarıyla konuștukları dil (9. Sinıf örneklemi)

\begin{tabular}{|c|c|c|c|c|c|c|c|c|}
\hline & $\mathbf{T i}$ & Güney & Eski & Polo & Eski & Diğer & Diğer & plam \\
\hline & & Avrupa & Yugoslavya & & SSCB & Avrupa & & \\
\hline Sadece Almanca & 393 & 342 & 294 & 328 & 413 & 700 & 283 & 2811 \\
\hline & $6 \%)$ & $(73 \%)$ & $(71 \%)$ & $(74 \%)$ & $(57 \%)$ & $(82 \%)$ & $(77 \%)$ & $(68 \%)$ \\
\hline Coğur & & 81 & 81 & 76 & 195 & 113 & 64 & 846 \\
\hline $\begin{array}{l}\text { (Baz } \\
\text { anad }\end{array}$ & $3 \%)$ & $(17 \%)$ & $(20 \%)$ & 70 & $(27 \%)$ & $(13 \%)$ & $(17 \%)$ & $1 \%)$ \\
\hline 0 & 122 & 37 & 24 & 28 & 82 & 18 & 13 & 302 \\
\hline Gelc & $(14 \%)$ & $(8 \%)$ & $(6 \%)$ & $6 \%)$ & $(11 \%)$ & $(2 \%)$ & $(4 \%)$ & $(7 \%)$ \\
\hline 1 & & & & & & & & \\
\hline Sade & 32 & 6 & 4 & 7 & 16 & 12 & 3 & 95 \\
\hline Ülk & $(4 \%)$ & $(1 \%)$ & $(1 \%)$ & $(2 \%)$ & $(2 \%)$ & $(1 \%)$ & $(1 \%)$ & $(2 \%)$ \\
\hline Ben & 12 & 4 & 6 & 5 & 11 & 5 & 1 & 40 \\
\hline & $(1 \%)$ & $(1 \%)$ & $(1 \%)$ & $(1 \%)$ & $(2 \%)$ & $(1 \%)$ & $(0 \%)$ & $(1 \%)$ \\
\hline 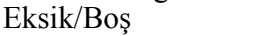 & 5 & 1 & 7 & 2 & 2 & 6 & 5 & 28 \\
\hline Bırakmıs & $(1 \%)$ & $(0 \%)$ & $(2 \%)$ & $(0 \%)$ & $(0 \%)$ & $(1 \%)$ & $(1 \%)$ & $(1 \%)$ \\
\hline & & & & & & & & \\
\hline Toplam & $\begin{array}{c}847 \\
100 \%\end{array}$ & $\begin{array}{c}471 \\
100^{\circ}\end{array}$ & 416 & 446 & 719 & 854 & 369 & 4122 \\
\hline
\end{tabular}

Kaynak: Ulusal Eğitim Paneli Araştırması 9. Sınıf Örneklemi (2011)

göçmen gençlerin göç edilen ülkenin ana dilini daha sık kullanması ve bu topluma kültürel olarak adapte olabilmesi zorlaşacaktır.

Tablo 8, öğrencilere sorulan "Bütün arkadaşlarınızı göz önüne alırsak, okul veya dışında, arkadaşlarının ne kadarı göçmendir veya göçmenlik geçmişi vardır?" sorusuna verdikleri yanıtları bildirmektedir. Görüldüğü üzere, tıpkı Türkçe kullanımında olduğu gibi arkadaşlık bağları açısından Alman akranlarıyla en zayıf arkadaşlık bağları olan grupların Türkiye ve eski SSCB asıllı öğrenciler olduğu ortaya çıkmaktadır. Her iki grup için hepsi cevabının verilme oranı \%30 veya üzerindedir. Yarıdan fazla seçeneği de göz önüne alınırsa, bu iki grubun yarısını arkadaşlarının çoğunluğunu veya hepsinin 
Tablo 8

Öğrencilerin arkadașlarının göçmenlik geçmişi (9. Sinıf örneklemi)

\begin{tabular}{|c|c|c|c|c|c|c|c|c|c|}
\hline & \multirow[t]{2}{*}{ Alman } & \multicolumn{2}{|c|}{ Türkiye Güney } & \multirow{2}{*}{$\begin{array}{c}\text { Eski } \\
\text { Yugoslavya }\end{array}$} & \multirow[t]{2}{*}{ Polonya } & \multirow{2}{*}{$\begin{array}{c}\text { Eski } \\
\text { SSCB }\end{array}$} & \multirow{2}{*}{$\begin{array}{l}\text { Diğer } \\
\text { Avrupa }\end{array}$} & \multirow[t]{2}{*}{ Diğer } & \multirow[t]{2}{*}{ Toplam } \\
\hline & & & Avrupa & & & & & & \\
\hline Hiç Yok / & 6398 & 129 & 148 & 98 & 160 & 118 & 398 & 66 & 7515 \\
\hline Cok Az & $(64 \%)$ & $(15 \%)$ & $(32 \%)$ & $(24 \%)$ & $(36 \%)$ & $(16 \%)$ & $(47 \%)$ & $(18 \%)$ & $(53 \%)$ \\
\hline Yarıdan Az & 2517 & 116 & 129 & 76 & 111 & 128 & 250 & 69 & 3396 \\
\hline & $(25 \%)$ & $(14 \%)$ & $(27 \%)$ & $(18 \%)$ & $(25 \%)$ & $(18 \%)$ & $(29 \%)$ & $(19 \%)$ & $(24 \%)$ \\
\hline Yarıs1 & 720 & 160 & 78 & 67 & 69 & 123 & 117 & 70 & 1404 \\
\hline & $(7 \%)$ & $(19 \%)$ & $(17 \%)$ & $(16 \%)$ & $(16 \%)$ & $(17 \%)$ & $(14 \%)$ & $(19 \%)$ & $(10 \%)$ \\
\hline Yarıdan & 207 & 168 & 51 & 52 & 48 & 135 & 43 & 66 & 770 \\
\hline Fazla & $(2 \%)$ & $(20 \%)$ & $(11 \%)$ & $(13 \%)$ & $(11 \%)$ & $(19 \%)$ & $(5 \%)$ & $(18 \%)$ & $(5 \%)$ \\
\hline Hepsi / & 176 & 273 & 65 & 121 & 58 & 215 & 45 & 98 & 1051 \\
\hline Neredeyse & $(2 \%)$ & $(32 \%)$ & $(14 \%)$ & $(29 \%)$ & $(13 \%)$ & $(30 \%)$ & $(5 \%)$ & $(27 \%)$ & $(7 \%)$ \\
\hline Hepsi & & & & & & & & & \\
\hline Eksik / Boş & 22 & 1 & 0 & 2 & 0 & 0 & 1 & 0 & 26 \\
\hline Birakmış & $(0 \%)$ & $(0 \%)$ & $(0 \%)$ & $(0 \%)$ & $(0 \%)$ & $(0 \%)$ & $(0 \%)$ & $(0 \%)$ & $(0 \%)$ \\
\hline (Missing) & & & & & & & & & \\
\hline Toplam & $\begin{array}{l}10,040 \\
(100 \%)\end{array}$ & $\begin{array}{c}847 \\
(100 \%)\end{array}$ & $\begin{array}{c}471 \\
(100 \%)\end{array}$ & $\begin{array}{c}416 \\
(100 \%)\end{array}$ & $\begin{array}{c}446 \\
(100 \%)\end{array}$ & $\begin{array}{c}719 \\
(100 \%)\end{array}$ & $\begin{array}{c}854 \\
(100 \%)\end{array}$ & $\begin{array}{c}369 \\
(100 \%)\end{array}$ & $\begin{array}{c}13793 \\
(100 \%)\end{array}$ \\
\hline
\end{tabular}

Kaynak: Ulusal Eğitim Paneli Araştırması 9. Sınıf Örneklemi (2011)

Tablo 9

Göçmen geçmişli ögrencilere göre mahallerindeki (kendi ülkelerinden gelmiş) göçmen topluluğun oranı (9. Sinıförneklemi)

\begin{tabular}{lcccccccc} 
& Türkiye Güney & $\begin{array}{c}\text { Eski } \\
\text { Avrupa }\end{array}$ & Yugoslavya & Polonya & $\begin{array}{c}\text { Eski } \\
\text { SSCB }\end{array}$ & $\begin{array}{c}\text { Diğer } \\
\text { Avrupa }\end{array}$ & Diğer & Toplam \\
\hline \%10'dan Az & 211 & 271 & 223 & 240 & 231 & 609 & 206 & 1991 \\
& $(25 \%)$ & $(58 \%)$ & $(54 \%)$ & $(54 \%)$ & $(32 \%)$ & $(71 \%)$ & $(56 \%)$ & $(48 \%)$ \\
\%11-\%20 Aras1 & 125 & 70 & 64 & 76 & 122 & 84 & 52 & 593 \\
& $(15 \%)$ & $(15 \%)$ & $(15 \%)$ & $(17 \%)$ & $(17 \%)$ & $(10 \%)$ & $(14 \%)$ & $(14 \%)$ \\
\%21-\%30 Aras1 & 95 & 39 & 41 & 46 & 101 & 49 & 43 & 414 \\
& $(11 \%)$ & $(8 \%)$ & $(10 \%)$ & $(10 \%)$ & $(14 \%)$ & $(6 \%)$ & $(12 \%)$ & $(10 \%)$ \\
\%31-\%40 Aras1 & 111 & 26 & 25 & 20 & 62 & 36 & 19 & 299 \\
& $(13 \%)$ & $(6 \%)$ & $(6 \%)$ & $(5 \%)$ & $(9 \%)$ & $(4 \%)$ & $(5 \%)$ & $(7 \%)$ \\
\%41-\%50 Aras1 & 105 & 27 & 19 & 30 & 85 & 32 & 14 & 312 \\
& $(12 \%)$ & $(6 \%)$ & $(5 \%)$ & $(7 \%)$ & $(12 \%)$ & $(4 \%)$ & $(4 \%)$ & $(8 \%)$ \\
\%50'den Fazla & 199 & 38 & 35 & 31 & 116 & 38 & 32 & 489 \\
& $(24 \%)$ & $(8 \%)$ & $(8 \%)$ & $(7 \%)$ & $(16 \%)$ & $(5 \%)$ & $(9 \%)$ & $(12 \%)$ \\
Eksik/Boş B1- & 1 & 0 & 9 & 3 & 2 & 6 & 3 & 24 \\
rakm1ş & $(0 \%)$ & $(0 \%)$ & $(2 \%)$ & $(1 \%)$ & $(0 \%)$ & $(1 \%)$ & $(1 \%)$ & $(1 \%)$ \\
(Missing) & & & & & & & & \\
Toplam & 847 & 471 & 416 & 446 & 719 & 854 & 369 & 4122 \\
& $(100 \%)$ & $(100 \%)$ & $(100 \%)$ & $(100 \%)$ & $(100 \%)$ & $(100 \%)$ & $(100 \%)$ & $(100 \%)$ \\
\hline Kaynak: Uly
\end{tabular}

Kaynak: Ulusal Eğitim Paneli Araştırmas1 9. Sınıf Örneklemi (2011)

göçmen geçmişli olanlar oluşturmaktadır. Almanya ile daha yakından bütünleşmiş Avrupalı, Güney Avrupalı ve Polonyalı gruplar için ise göçmen geçmişi olan arkadaşların dağılımı tam tersi yönündedir. Bu grupların önemli bir çoğunluğu aynı soruya hiç yok veya yarıdan az cevabını vermektedirler. Alman akranlarıyla bu düzeyde bir bütünleşme, bu gruplar için hem daha iyi 
Almanca konuşma ve okuma becerisine hem de Alman toplumuna kültürel olarak daha fazla yakınlaşma olanağına yol açacaktır. Almanca dili kullanımı ve Alman akranlarla arkadaşlık verileri UEPA'nın 5. sınıf örnekleminde çok büyük oranda cevapsız bırakıldığı için incelemeye elverişli değildir.

\section{İkamete Dayalı Tecrit}

Almanya' da ikamete dayalı tecrit (segregasyon) üzerine çalışmalar kısıtlıdır. Almanya'daki göçmenlerin mahalle ölçeğinde tecrit edilip edilmedikleri üzerine yapılan çalışmaların kapsamı bize bu konuda açık bir bilgi sunmamaktadır. An itibarıyla adrese dayalı idari verilere erişim imkânı da bulunmamaktadır. Ancak ülkenin her büyük şehrinde, özellikle Alman sanayi üretiminin merkezi sayılabilecek federal eyaletlerin büyük kentlerinde ve başkent Berlin'de "Türk mahallesi" ve "Rus mahallesi” diye adlandırılan yerleşim yerleri bulunmaktadir.

UEPA 9. sinıf anketindeki bir soru, var olan ikamete dayalı tecritle ilgili bize bir fikir verebilir: "Mahallenizde oturanların veya onların ailelerinin yüzde kaçı seninle aynı ülkeden Almanya'ya göç etmiş insanlardan oluşmaktadır?" (Skopek, Pink ve Bela, 2013, s. 811). Elbette, bu soruya öğrencilerin sahih bir cevap vermesi mümkün değildir çünkü mahallelerindeki kendi ülkelerinden göçmüş insanları sayabilecek durumda değildirler. Ancak yine de öğrencilerin verdiği cevaplar göçmen geçmişli gruplar arasında öznel de olsa bir farklılık olduğuna işaret etmektedir.

Tablo 9'a göre her dört Türkiye asılllı öğrenciden biri, mahallesinde yaşayan Türkiyeli göçmenlerin nüfusunun o mahallenin sakinlerinin yarısından fazlasını oluşturduğunu ifade etmiştir. Bu oranın diğer bütün göçmen gruplar arasında - eski SSCB'den gelen grup hariç- \%10'un altında olduğu görülmektedir. SSCB asıllı öğrenciler arasında da bu oran \%16'dır. Benzer bir şekilde mahallesinde aynı göçmen kökenine sahip insanların oranının \%10'unun altında olduğunu söyleyenlerin oranı Türkiye ve SSCB asıllı grup dışındakiler arasında \%50'nin üzerindedir. Bu iki grup ise diğerlerine nazaran etnik olarak daha fazla tecrit edilmiş mahallelerde ikamet etmektedirler.

Bu soru 5. sınıf soru anketinde yer almadığı için, o örneklemin verisiyle karş1laştırma yapmak mümkün değildir. Elbette sorunun öznel niteliği de göz 
önüne alınırsa, bu bilgilerin başka veri kaynaklarıyla ve özellikle de idari veriler kullanarak teyit edilmesi gerekmektedir.

Yine de bu bilgiler 1şı̆̆ında, geçici de olsa, Türkiye ve eski SSCB asıllı öğrencilerin ikamete dayalı olarak en fazla tecrit edilmiş göçmen grupları oldukları sonucuna temkinli de olsa ulaşılabilir. Tecrit içinde yaşamanın dil kullanımı, kültürel bütünleşme ve toplumun geri kalanına ayak uydurma dışında da olumsuz sonuçları olacaktır. Almanya'da hem ilköğretim hem de ortaöğretim düzeyinde okuma çağına gelen çocukların kendilerine yakın okullardan birine yerleştirildiği düşünülürse, göçmenlerin yoğunlukla yaşadığı okullardaki göçmen nüfusu da yüksek olacaktır.

Yüksek göçmen nüfusa sahip okullarda eğitimin seviyesi ve öğretmenlerin beklentisi sınıflarda var olan ortalama seviyeye göre düşebilir. Ayrıca, daha tecrübeli öğretmenler yüksek göçmen nüfuslu okulları tercih etmeyebilir veya bu okullara yeterli altyapı yatırımları uygulanmayabilir (bkz. Orfield ve Lee, 2005).

\section{Sonuç}

Bu çalışmada Almanya Ulusal Eğitim Paneli Araştırması (UEPA) tarafindan yürütülen ve 2010-2011 akademik yılından itibaren Almanya çapında toplanan verilerden yararlanılarak Almanya'daki Türkiye asıllı genç göçmen nüfusun eğitime başarısı ve eğitim firsatları incelenmiştir. Ulusal çapta istatistik olarak temsil kabiliyeti bulunan 5. ve 9. sınıf örneklemleri, Türkiyeli öğrencilerin hem ortaöğretimde yerleşilen okul tipi hem de okuma ve matematik başarısı olarak hem Alman hem de birçok farklı göçmen grubuna mensup akranlarının gerisindedirler.

Alman eğitim sisteminde, ortaöğretimde yerleşilen okul tipinin üniversiteye girişte tayin edici bir rolü olduğu göz önüne alındığında, ilköğretim ve ortaöğretim çağında yaşanılan bu eşitsizliklerin Türkiye asıllı öğrencilerin yaşam fursatlarını uzun vadede olumsuz etkileyeceği aşikardır. Çalışmalardan ortaya çıkan en önemli sonuç, Türkiye asıllı genç nüfus hem akademik liseden mezun olma hem de lise boyunca özellikle Almanca başarısı açısından en dezavantajlı grup olduğudur.

Eğitim alanında yaşanan bu eşitsizlikler 'parçalı asimilasyon' kuramı çerçevesinde tartışılmış, ve farklı göçmen grupların farklı tecrübelerle geldik- 
leri toplumlarla bütünleştiği ifade edilmiştir. Başta Türkiye ve eski SSCB'li topluma mensup öğrencilerin yaşadığı eşitsizlikleri açıklamak için 5. ve 9 . sınıf öğrencileri arasında üç temel konu ele alınmıştır: Ailenin Eğitim Durumu ve Sosyoekonomik Statüsü; Almanca Kullanımı ve Arkadaşlık Bağları ve İkamete Dayalı Tecrit. Birbiriyle ilintili ancak analitik olarak birbirinden bağımsız bu alanların hepsinde Türkiye asıllı toplum hem Alman hem de diğer göçmen gruplara mensup akranlarına nazaran en dezavantajlı grup konumundadır. Türkiye asıllı öğrenciler Almanca dilini gündelik hayatta en az kullanan gruptur. Öte yandan, oturdukları mahalleler açısından da etnik olarak en fazla tecrit edilmiş göçmen topluluğunun da Türkiyeli öğrenciler olduğu anlaş1maktadır. Almanya'ya varışlarından 50 yıl sonra, Türkiyeli öğrenciler hem en az eğitimli ailelerden gelen hem evlerinde en az sayıda kitap bulunan hem aile içinde ve arkadaşlarıyla Almanca dilini en az kullanan hem de ikamete dayalı olarak en çok tecrit edilmiş gruptur. Türkiye asıllı toplumun Alman toplumuyla bütünleşmesiyle ilgili sorunlar daha genç nesilleri de etkilemeye devam etmektedir. Eski SSCB ülkelerinden gelen göçmen çocuklarının da ikamete dayalı tecrit ve arkadaşlık bağları gibi bazı ölçütlere bakıldığında Türkiye asıllı göçmen gençlik kadar Alman toplumyla bütünleşme açısından sıkıntılar yaşadığı gözlemlenebilir. Ancak bu grubun eğitim başarısı ve eğitim firsatları açısından Türkiye asıllı gençlik kadar problemleri bulunmamaktadır. Daha da önemlisi, tarihsel olarak eski SSCB'liler henüz kısa süre önce Almanya'ya göç etmiş bir topluluktur. Bu sebeple, bu grubun bütünleşme konusunda birtakım sorunlar yaşaması anlaşılabilir. Ancak Türkiye asıllı toplumun yeni nesilleri açısından da bütünleşme sorunu devam etmektedir.

Sonuç olarak görülüyor ki, yalnız eğitim düzeyi ve sosyoekonomik statü değil, dil kullanımı ve çeşitli şekillerde ev sahibi toplumdan tecrit olma sorunları da Türkiye asıllı toplumunu etkilemeye devam etmektedir. Eğitim politikası ve sosyal politika olarak, Türkiyeli toplumun etnik grup olarak tecrit edilmesinin önüne geçilmesi ve erken yaşta Almanca kullanma ve becerisinin Türkiyeli gençlik arasında yaygınlaştırılması, var olan eğitime erişim ve eğitim fırsatları alanındaki eşitsizliklerin önüne geçilmesi için hayati önemdedir. Bu aşamada, Almanya' da yaşayan Türkiyeli toplum, Alman ve Türkiye hükümetlerinin ortak politika üretmesine kuşkusuz ihtiyaç duyacaktır. 


\section{Kaynakça/References}

Abadan-Unat, N. (2002). Bitmeyen göç: konuk işçilikten ulus-ötesi yurttaşlığa (Vol. 1). İstanbul: İstanbul Bilgi Üniversitesi Yayınları.

Acar, T. (2016). Mechanisms of and barriers to educational integration of immigrant youth in Germany. Unpublished Dissertation. The University of Wisconsin-Madison.

Allmendinger, J. (1989). Educational systems and labor market outcomes. European sociological review, 5(3), 231-250.

Ammermueller, A. (2005). Educational opportunities and the role of institutions.

ZEW-Centre for European Economic Research Discussion Paper, (05-044).

Bankston III, C. L., \& Zhou, M. (2002). Social capital and immigrant children's achievement. In Schooling and social capital in diverse cultures (pp. 13-39). Emerald Group Publishing Limited.

Blau, P. M., \& Duncan, O. D. (1967). The American occupational structure. New York: Free Press.

Blossfeld, H.-P., Roßbach, H.-G., \& von Maurice, J. (Eds.). (2011). Education as a Lifelong Process: The German National Educational Panel Study (NEPS). [Special Issue] Zeitschrift für Erziehungswissenschaft, 14.

Buchmann, C., \& Park, H. (2009). Stratification and the formation of expectations in highly differentiated educational systems. Research in Social Stratification and Mobility, 27(4), 245-267.

Çelik, Ç. (2011). The Process of Leaving School and Meaning of Schooling: The Case of Turkish School Leavers in Germany. Unpublished Dissertation, University of Bremen.

Diefenbach, H. (2008). Bildungschancen und Bildungs (miss) erfolg von ausländischen Schülern oder Schülern aus Migrantenfamilien im System schulischer Bildung. Bildung als Privileg: Erklärungen und Befunde zu den Ursachen der Bildungsungleichheit, 221-245.

Federal İstatistik Bürosu [Statistisches Bundesamt]. (2011). Statistisches Jahrbuch 2010 für die Bundesrepublik Deutschland. Statistisches Bundesamt.

Grodsky, E., \& Jackson, E. (2009). Social stratification in higher education. The Teachers College Record, 111(10), 2347-2384.

Hanushek, E. A. (2005). The economics of school quality. German Economic Review, $6(3), 269-286$.

Haug, S. (2003). Interethnische Freundschaftsbeziehungen und soziale Integration.

KZfSS Kölner Zeitschrift für Soziologie und Sozialpsychologie, 55(4), 716-736.

Kalter, F. (2011). The Second Generation in the Labor Market: Explaining the Turkish Exception. Alba \& M. C. Waters içinde, The Next Generation: Immigrant Youth in a Comparative Perspective (pp. 166-184), New York, NY: NYU Press. 
Kalter, F., \& Granato, N. (2007). Educational hurdles on the way to structural assimilation in Germany. In Proceedings of the British Academy, vol. 137 (pp. 271-319). Oxford, UK: Oxford University Press Inc.

Kalter, F., \& Kogan, I. (2014). Migrant networks and labor market integration of immigrants from the former Soviet Union in Germany. Social Forces, 92(4), 1435-1456.

Kao, G., \& Tienda, M. (1998). Educational aspirations of minority youth. American journal of education, 349-384.

Kogan, I. (2011). New immigrants—old disadvantage patterns? Labour market integration of recent immigrants into Germany. International Migration, 49(1), 91-117.

Kristen, C. (2003). School choice and ethnic school segregation: Primary school selection in Germany. Waxmann Verlag.

Kristen, C., \& Olczyk, M. (2013). Ethnische Einbettung und Bildungserfolg. In

Bildungskontexte (pp. 353-403). Springer Fachmedien Wiesbaden.

Kristen, C., Edele, D., Kalter, F., Kogan, I., Schulz, B., Stanat, P., \& Will, G. (2011). The education of migrants and their children across the life course. Zeitschrift für Erziehungswissenschaft, 14(2), 121-137.

Kroneberg, C. (2008). Ethnic communities and school performance among the new second generation in the United States: Testing the theory of segmented assimilation. The Annals of the American Academy of Political and Social Science, 620(1), 138-160.

Maaz, K., Baethge, M., Brugger, P., Füssel, H. P., Hetmeier, H. W., Rauschenbach, T., ark. (2016). Bildung in Deutschland 2016. Education in Germany 2016.

Neugebauer, M., Reimer, D., Schindler, S., \& Stocké, V. (2013). Inequality in transitions to secondary school and tertiary education in Germany. Determined to succeed, 56-88. In Jackson M. (ed.), Determined to succeed? Performance versus choice in educational attainment (pp. 56-88). Stanford: Stanford University Press.

Orfield G, \& Lee C. (2005). Why Segregation Matters: Poverty and Educational Inequality. Cambridge, MA: Civil Rights Proj., Harvard Univ.

Portes, A., \& Zhou, M. (1993). The new second generation: Segmented assimilation and its variants. The annals of the American academy of political and social science, 530(1), 74-96.

Portes, A., \& Rumbaut, R. G. (2001). Legacies: The story of the immigrant second generation. Univ of California Press.

Portes, A., \& Rumbaut, R. G. (2005). Introduction: The second generation and the children of immigrants' longitudinal study. Ethnic and Racial Studies,28(6), 983-999.

Schulz, B., \& Leszczensky, L. (2016). Native friends and host country identification among adolescent immigrants in Germany: The role of ethnicboundaries. International Migration Review, 50(1), 163-196. 
Skopek, J., Pink S. \& Bela, D. (2013). Starting Cohort 4: 9th Grade (SC4). SUF Version 1.1.0. Data Manual. NEPS Research Data Paper. In National Educational Panel Study (NEPS). Bamberg, University of Bamberg. https://www.nepsdata.de/Portals/0/NEPS/ Datenzentrum/Forschungsdaten/SC4/1-1-0/SC4_1-1-0_DataManual_en.pdf

Tarelli, I, Bos, W. \& Bremerich-Vos, A. Germany. (2012). In PIRLS 2011 Encyclopedia: Education Policy and Curriculum in Reading. Volume 1: AK." International Association for the Evaluation of Educational Achievement.

Wegmann, K. M. (2014). Shaping a new society: Immigration, integration, and schooling in Germany. International Social Work, 57(2), 131-142.

Zhou, M., \& Bankston, C. (1998). Growing up American: How Vietnamese children adapt to life in the United States. Russell Sage Foundation.

\section{Notlar}

i Bu çalışmada kullanılan veriler Ulusal Eğitim Paneli Araştırması'nın (UEPA; National Educational Panel Study, NEPS) Kohort 3-5. Sinıf(doi:10.5157/NEPS:SC3:7.0.1) ve Kohort 4-9. Sinıf (doi:10.5157/NEPS:SC4:9.1.1)

örneklemlerinden alınmıştır. 2008 ve 2013 yılları arasında UEPA anketi Alman Federal Eğitim ve Araştırma Bakanlığı (BMBF) tarafından fonlanan Ampirik Eğitim Araştırılmaları Teşviki çerçevesinde yürütülmüş. 2014 yılı itibarıyla UEPA anketi, Bamberg Üniversitesi'nde bulunan Leibniz Eğitim Enstitüsü (LIfBi) önderliğinde ulusal bir ağ ile beraber yürütülmektedir.

ii 15-yaşındaki öğrenciler arasında, 2003 yılında birincisi yapılan PISA (Uluslararası Öğrenci Değerlendirme Programı) sonuçlarında Alman öğrenciler beklentilerin çok gerisinde bir performans sergilemişlerdir. Bu Almanya'da "PISA-Şoku” olarak değerlendirilmiş ve Almanya'nın federal eğitim politikalarından sorumlu olan birim (Kulturministerkonferenz), konunun üzerine daha dikkatli şekilde eğilmeye başlamıştır. Özellikle 2003 sonrasında Alman Federal Hükümeti özellikle göçmenler arasında yaşanan eğitim eşitsizlikleri konusunu gündeme almış ve bu yönde sosyal politika üretmeye başlamıştır.

iii Almanya' da resmi olarak göçmenlik statüsü "göçmenlik geçmişine sahip olanlar" (Personen mit Migrationshintergrund) diye nitelendirilmektedir. Alman devleti bu bilgiyi nüfus sayımları vasıtasıyla toplamaktadır. 